\title{
Construction and disruption of spatial memory networks during development
}

\author{
Tallie Z. Baram, ${ }^{1,2,3}$ Flavio Donato, ${ }^{4,5}$ and Gregory L. Holmes ${ }^{6}$ \\ ${ }^{1}$ Department of Anatomy/Neurobiology; ${ }^{2}$ Department of Pediatrics; ${ }^{3}$ Department of Neurology, University of California-Irvine, Irvine, \\ California 92697, USA; ${ }^{4}$ Kavli Institute for Systems Neuroscience and Centre for Neural Computation, Norwegian University of Science \\ and Technology, Trondheim 7491, Norway; ${ }^{5}$ Biozentrum, Department of Cell Biology, University of Basel 4056, Switzerland; \\ ${ }^{6}$ Department of Neurological Sciences, University of Vermont College of Medicine, Burlington, Vermont 05401, USA
}

\begin{abstract}
Spatial memory, the aspect of memory involving encoding and retrieval of information regarding one's environment and spatial orientation, is a complex biological function incorporating multiple neuronal networks. Hippocampus-dependent spatial memory is not innate and emerges during development in both humans and rodents. In children, nonhippocampal dependent egocentric (self-to-object) memory develops before hippocampal-dependent allocentric (object-to-object) memory. The onset of allocentric spatial memory abilities in children around 22 mo of age occurs at an age-equivalent time in rodents when spatially tuned grid and place cells arise from patterned activity propagating through the entorhinal-hippocampal circuit. Neuronal activity, often driven by specific sensory signals, is critical for the normal maturation of brain circuits This patterned activity fine-tunes synaptic connectivity of the network and drives the emergence of specific firing necessary for spatial memory. Whereas normal activity patterns are required for circuit maturation, aberrant neuronal activity during development can have major adverse consequences, disrupting the development of spatial memory. Seizures during infancy, involving massive bursts of synchronized network activity, result in impaired spatial memory when animals are tested as adolescents or adults. This impaired spatial memory is accompanied by alterations in spatial and temporal coding of place cells. The molecular mechanisms by which early-life seizures lead to disruptions at the cellular and network levels are now becoming better understood, and provide a target for intervention, potentially leading to improved cognitive outcome in individuals experiencing early-life seizures.
\end{abstract}

Spatial memory networks encompass precisely interacting cell populations within the hippocampal formation and interacting cortical regions. The development of these circuits involves activity- and sensory-signal-dependent and independent components. Orchestrated development of these networks is crucial for memory function throughout life: conversely, disruptions of memory network development arise at molecular, cellular and circuit levels with major, clinically relevant cognitive deficits. Our understanding of how and when these different memory systems emerge during the course of human development has been expanding rapidly. In this review, the developmentally regulated construction of human and rodent functional memory networks is discussed. This is followed by a discussion of how insult-related disruption of this development can inform the fundamental principles of memory as well as clarify disease mechanisms.

\section{Spatial memory development in humans}

Memory is a complex biological function incorporating multiple neuronal networks. Likewise, the taxonomy of memory is convoluted. Current thought is that there are at least two major kinds of memory, declarative (or explicit), memory and procedural, often referred to as implicit or nondeclarative memory (Zola-Morgan et al. 1983; Squire 1986; Squire et al. 1990). Declarative memory refers to memory that can be declared in some way and includes the conscious recollection of facts and events (Squire and Zola-Morgan 1985, 1988; Squire et al. 1990; Zola-Morgan and Squire 1993). Within the declarative memory domain there is a further distinc-

\section{Corresponding author: gregory.holmes@uvm.edu}

Article is online at http://www.learnmem.org/cgi/doi/10.1101//m.049239.118. tion between semantic and episodic memory. Semantic memory refers to memory for factual information, while episodic memory refers to memory of a personal experience, that is memory of "what-where-when." Procedural memory refers to information that is reflected in behavior but that cannot be consciously recalled. For example, highly practiced motor behaviors such as driving a car or playing the piano are examples of procedural memory skills.

Spatial memory is the aspect of memory responsible for encoding and retrieval of information regarding one's environment and spatial orientation. In rodents, spatial memory is considered equivalent to declarative memory in humans (Bunsey and Eichenbaum 1996; Crystal and Smith 2014; Eichenbaum and Cohen 2014). Spatial coding can be allocentric (object-to-object) where the location of one object is defined relative to the location of other objects or egocentric (self-to-object) where the location of objects in space is relative to the body axes of the self. Allocentric, semantic, and episodic memory are dependent on the hippocampus, entorhinal cortex (EC), and surrounding structures (Scoville and Milner 1957; Zola-Morgan et al. 1986; Hoscheidt et al. 2010; Banta Lavenex et al. 2014) whereas egocentric navigation involves the dorsal striatum and connected structures. The latter system encodes routes and integrated paths and, when overlearned, becomes procedural memory (Ribordy et al. 2017).

\footnotetext{
- 2019 Baram et al. This article is distributed exclusively by Cold Spring Harbor Laboratory Press for the first 12 months after the full-issue publication date (see http://learnmem.cshlp.org/site/misc/terms.xhtml). After 12 months, it is available under a Creative Commons License (AttributionNonCommercial 4.0 International), as described at http://creativecommons. org/licenses/by-nc/4.0/.
} 
Declarative memory is not an innate faculty and emerges during early childhood. Infantile amnesia, first described by Sigmund Freud in the late nineteenth century (for review, see Josselyn and Frankland 2012), is the term used to describe the fact that adults have essentially no explicit memories from the first $2-3 \mathrm{yr}$ of life, whereas childhood amnesia describes the observation that adults have fewer explicit memories from 3 to $7 \mathrm{yr}$ of age than would be expected based on normal forgetting alone. The phenomena of infantile and childhood amnesia suggest that hippocampusdependent declarative memory may not be evident during the first few years of life. However, it is important to note that by the age of $6 \mathrm{mo}$, infants have acquired at least some rudimentary memory skills (Rovee-Collier et al. 1980, 1985; Hayne et al. 1987, 1991; Rovee-Collier and Hayne 1987; Hayne and Rovee-Collier 1995; Collie and Hayne 1999; Hayne and Herbert 2004). For example, in the visual paired comparison task (also referred to as a habituation and novelty-preference paradigm), an infant will spend less time looking at a familiar object relative to a novel object. Notably, this task is probably not hippocampus-dependent and occurs because of modifications of a perceptual-cognitive process (i.e., priming processes) without any explicit knowledge or reference to the study context (Mullally and Maguire 2014). Likewise, although infants as young as 3 mo can be taught to activate a crib mobile by means of operant foot kicks (Rovee-Collier et al. $1980)$, this test is considered to be nondeclarative in nature (Bauer 2008; Mullally and Maguire 2014). It has been suggested that this operant task most likely depends on the cerebellum and brain stem, which mature prior to the hippocampus and which likely support a primitive, nondeclarative memory system (Bauer 2008; Mullally and Maguire 2014).

Egocentric capabilities emerge prior to allocentric ones and tend to dominate the infant's spatial world for at least the first 6 mo of life (Lavenex and Banta 2013). The use of cues or landmarks to remember spatial locations begins to appear at the end of the first year of life (Bushnell et al. 1995; Lew et al. 2000). Path integration, often referred to as dead reckoning, becomes apparent in children during the second year of life (Bremner et al. 1994). Path integration is the process of continuous integration of idiothetic cues, such as vestibular, proprioception, odors, motor efference and optic flow (information from the visual system signaling how fast the visual world is moving past the eyes) that allows for successful navigation to a specific goal (Wylie et al. 1999; Wallace et al. 2002a,b; Sjolund et al. 2018). There is considerable evidence that egocentric spatial memory is not dependent on the hippocampus (Vorhees and Williams 2014). Individuals with hippocampal and EC damage do as well on a path integration task as individuals with normal hippocampi and EC (Shrager et al. 2008).

In contrast, elegant experiments support the notion that allocentric spatial memory abilities in children emerge around 22 mo of age (Newcombe et al. 2007; Ribordy et al. 2013, 2017). Specifically, in a series of experiments by Ribordy et al. (2013, 2017), children were asked to find rewards hidden beneath cups in an open-field arena, over repeated trials. In the experiment children were asked to locate candy hidden under one of four inverted cups placed in an arena that was surrounded on three sides by opaque curtains, thus preventing the child from using aligned or adjacent objects as uncontrolled visual guidance cues. The child entered the arena through four separate entry/exit points which precluded the child from using egocentric cues. In the local cue condition, a red cup concealed the candy, thus allowing the investigators to assess whether the child could use a controlled visual guidance cue (nonhippocampus dependent) to find the candy. Since the local cue, the red cup, was readily visible to the child the hippocampus is not needed to remember distant cues. In the allocentric, hippocampus-dependent task, all four cups were identical, and children had to use an allocentric spatial representation of the environment to remember the rewarded cup's location. Whereas $80 \%$ of the children between 20 and 24 mo found the correct cup when given a local cue, only $30 \%$ of the children could find the candy in the allocentric spatial condition, in the absence of the local cue. In children 25-39 mo of age, 100\% found the candy in the local cue condition, and $84 \%$ in the allocentric condition. These findings support work by Newcombe et al. (2007) showing that children 22 mo of age and older benefited from the presence of distal visual objects when searching for objects buried in a sandbox, whereas younger children did not. The developmental timing of allocentric memory in children is further supported by studies by Hayne and Imuta (2011). These authors developed a hide-and-seek paradigm and assessed young children's (3and 4-yr-olds) ability to recollect the "what-where-when" of a hiding event.

Together, the above studies suggest that the development of episodic memory is protracted throughout early and middle childhood, although rudimentary episodic memory skills do appear to be in place by the age of 3 yr. There is increasing evidence that the ability to retain, as opposed to form episodic memories may be the aspect of this form of memory that develops later. While both 3- and 4-yr-old children form episodic memories, 3-yr-old children fail to retain those memories following a delay (Scarf et al. 2013). In contrast, 4-yr-old children retained episodic memories over delays of a day and a week. These data suggest that childhood amnesia might be a result of an inability to retain, rather than to form, an episodic memory.

Allocentric spatial learning and memory emerges at a time when the hippocampus is structurally and functionally approaching maturity. While hippocampal volume approximates that of the adult by 10 postnatal months (Kretschmann et al. 1986), neuronal differentiation and synaptogenesis in the hippocampus do not reach adult levels until 3-5 yr of age (Amaral and Dent 1981; Ribak et al. 1985; Seress and Mrzljak 1992; Seress and Ribak 1995). Functional connectivity can be inferred through the EEG, a dynamic measure of brain maturity (Marshall et al. 2002) with certain EEG patterns appearing as a function of age (Marshall et al. 2002). By age $2 \mathrm{yr}$, the EEG is quite similar to that of a young adult, with a well-developed, reactive $\theta$ rhythm of $7-8 \mathrm{~Hz}$, distinct centro-parietal rhythms and well-formed frontally dominant fast activity. Sleep spindles, brief distinct bursts of 10-15 Hz activity with a characteristic waxing and waning shape, are a key element of the EEG used to identify the onset of sleep and represent a gating function that signals deepening disengagement from the surrounding environment. In addition, spindles are believed to play an important functional role in sleep-dependent synaptic plasticity and memory consolidation (Fogel and Smith 2011). The morphology and oscillatory frequency of spindles are used as markers of the developing brain (Shibagaki et al. 1982; Nicolas et al. 2001; Crowley et al. 2002; Martin et al. 2013). By age 2 yr sleep spindles are well developed and do not change in density with increasing age (McClain et al. 2016).

The EEG has excellent temporal, but poor spatial resolution due to volume conduction of electrical sources to the scalp (Nunez and Westdorp 1994; Babiloni et al. 1995). While investigators are beginning to examine the functional connectivity of neural networks underlying declarative memory using functional MRI and magnetoencephalography (MEG) (Taylor et al. 2012; Satterthwaite et al. 2014), these methods are difficult to implement in toddlers and young children. Therefore, understanding the molecular, cellular, and network underpinnings of spatial cognition requires the use of animal models, with the information extrapolated back to children. To this end, we describe below the development of spatial memory in rodents while providing the underlying neurobiological substrates and developmental trajectories of spatial memory systems. 


\section{Development of spatial memory in rats}

Maneuvering safely through the environment is central to survival of almost all species. The ability to do this depends on learning and remembering locations. As with children, this capacity is encoded in the brain by two systems: one using distal cues outside the organism, allocentric navigation, and one using self-movement, internal cues, egocentric navigation (Vorhees and Williams 2014). This form of memory is tested in laboratory animals in many ways, including the T-maze, radial maze, Morris water maze, novel object location test, active avoidance test and Barnes maze.

Rats can use both "proximal" and "distal" cues to locate goal objects in their environments (Morris 1981; Rudy et al. 1987). In the proximal-cue situation, local stimuli that spatially cooccur with the goal are available to guide behavior. In the distal-cue situation, there are no cues that cooccur with the goal object; thus, to directly locate the goal, the rat must learn the spatial location of the goal relative to distal cues. These two navigation behaviors are dissociated during ontogeny. At postnatal (P) day 17 rats can use proximal cues to locate a safe platform. It is not until the rats are P20 that they demonstrate minimal evidence of distal-cue utilization (Rudy et al. 1987). These studies suggest that rat spatial navigation systems use egocentric navigation prior to P20 at which point allocentric spatial navigation skills emerge. Following the emergence of allocentric spatial skills there is a maturation of those skills until adult function is reached at approximately P40 (Schenk 1985; Brown and Kraemer 1997; Rossier and Schenk 2003).

\section{Physiological underpinnings of spatial memory in rodents} While the electrophysiological basis of allocentric spatial memory is complex, involving many neuronal ensembles and pathways, key anatomical and physiological processes sub-serving spatial memory are briefly reviewed here.

The hippocampus and EC are the two structures that have the most critical role in spatial cognition. The EC functions as a hub in a widespread network for spatial memory and is the main interface between the hippocampus and neocortex. The medial EC (mEC) and hippocampus interactions play an important role in spatial memories including memory formation, memory consolidation, and memory optimization in sleep. The superficial layers-layers II and III — of mEC project to the dentate gyrus and hippocampus: Layer II projects primarily to dentate gyrus and hippocampal region CA3; layer III projects primarily to hippocampal region CA1 and the subiculum (Dolorfo and Amaral 1998a,b). These layers receive input from other cortical areas, especially associational, perirhinal and parahippocampal cortices, as well as prefrontal cortex. The lateral EC projects to the dentate gyrus, CA3 and CA1 and processes information about individual items based on a local frame of reference, primarily using external sensory information (Knierim et al. 2014). The lateral EC provides the hippocampus with information about the content of an experience. Thus, as a whole, the EC receives highly processed input from every sensory modality, as well as input relating to ongoing cognitive processes.

A key cell type recorded in layers II and III of the mEC are grid cells (Fyhn et al. 2007; Moser et al. 2015; Rowland et al. 2016). Grid cells are principal neurons that have multiple precisely tuned firing fields which collectively signal the rat's changing position with an accuracy similar to place cells in the hippocampus. When these cells are recorded in a large two-dimensional environment, each neuron forms a periodic triangular array, or a "grid," that covers the entirety of the environment (Hafting et al. 2005) An important property of the $\mathrm{mEC}$ representation is the stereotypic manner across environments, regardless of the environment's particular landmarks (Hafting et al. 2005; Fyhn et al. 2007). The strict structure of the map and its independence from external cues indicate that firing positions must be integrated in these cells from speed and direction signals, without reference to the external environment, a process referred to as "path integration" (McNaughton et al. 2006).

The majority of the principal cells in layers II and III of the mEC have grid properties (Sargolini et al. 2006). Thus, most of the spatially selective cortical input to the hippocampus originate from the mEC grid cells. Within the hippocampus many of the cells receiving input from the mEC grid cells are neurons that fire action potentials (APs) that correspond to the animal's location within its environment and are therefore called place cells (O'Keefe and Dostrovsky 1971; O'Keefe 1973; Muller 1996; Hok et al. 2007). Specifically, these hippocampal pyramidal neurons selectively discharge when the animal enters the cell's firing field. Unlike grid cells, a given place cell will have only one, or a few, place fields in a typical small laboratory environment, but more in a larger region (Fenton et al. 2008). Because of the robust relationship between the activity of these "place cells" and the ongoing spatial behavior of rats (Muller 1996; Eichenbaum et al. 1999; Lenck-Santini et al. 2001, 2002; Dragoi and Buzsáki 2006) such signals provide the animal with an internal spatial representation, or cognitive map (O'Keefe and Nadel 1978; Muller 1996; O'Keefe et al. 1998; Hok et al. 2007) that guides spatial navigation.

Place cells are characterized by their precise temporal firing relationship within local hippocampal $\theta$ oscillations (Skaggs et al. 1996; Lenck-Santini and Holmes 2008). The extracted phase of local $\theta$ can be combined with APs from a rate map (Fig. 1A, next page) to create a phase map (Fig. 1B). Phase maps demonstrate that APs of the cell tend to fire at the later phases of $\theta$ at the periphery of the field and then precesses to earlier phases of $\theta$ as the animal moves through the field. Taken together, the rate and phase map illustrate that APs in the center of the field, where most of the APs occur, fire in a phase range between $240^{\circ}$ and $320^{\circ}$, agreeing with the rose plot (Fig. 1C), which shows that most APs fall within this phase range. Importantly, phase preference is dependent on the task. There is a shift in preferred phase of firing of a place cell in CA1 within the local $\theta$ cycle depending on the task the animal is doing. There are differences in phase preference when the animal is foraging for food pellets, a nonhippocampal task, and when the animal is engaged in a hippocampal-dependent task, such as the active avoidance test. In this test the animal uses spatial cues in the room to avoid a shock zone, which requires a heavy cognitive load (Fig. 1D). During a foraging session the cell's preferred position is in the ascending phase of $\theta$ while the same cell's preferred firing position during active avoidance, is in the descending phase of $\theta$. As seen in Figure 1D, the rose plot histogram demonstrates a shift of phase preference from $\sim 150^{\circ}$ in foraging to $\sim 240^{\circ}-270^{\circ}$.

The phase of firing in CA1 has an important role in the encoding and recall of information (Hasselmo 2005; Hasselmo and Stern 2014; Siegle and Wilson 2014; Kleen et al. 2016). Input from the EC, the major source of cortical projections to the hippocampus, is highest at the peak of local $\theta$ (Brankačk et al. 1993; Kamondi et al. 1998; Hasselmo and Stern 2014) and likely encodes sensory information from the environment (Hasselmo 2005; Hasselmo and Stern 2014). At this same phase, the hippocampus is more susceptible to long-term potentiation (LTP) (Hyman et al. 2003; Kwag and Paulsen 2009), which is consistent with the idea that this phase is optimized for encoding new information. At the trough of local $\theta$, CA1 cells receive greater input from CA3 (Hasselmo 2005; Hasselmo and Stern 2014). At this phase, stimulation of Schaffer collateral or temporoammonic inputs induces long-term depression (LTD) (Hyman et al. 2003; Kwag and Paulsen 2009), which could suppress information storage during memory retrieval.

Theta $(6-12 \mathrm{~Hz}$ in rats) rhythm and $\gamma$ oscillations $(25-100 \mathrm{~Hz})$ rhythms are critical oscillations in the neurophysiology of spatial cognition. Theta $(6-12 \mathrm{~Hz}$ in rats) is essential for the formation 
A

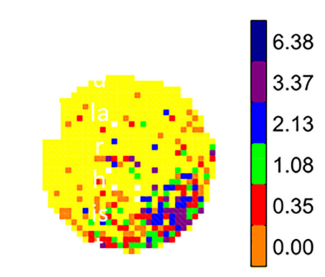

B

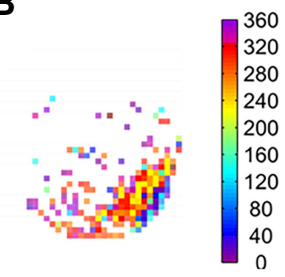

C

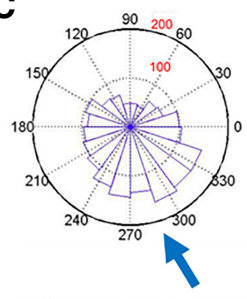

D
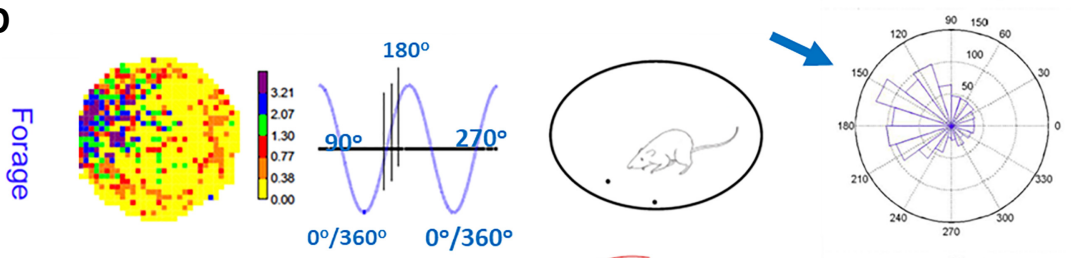
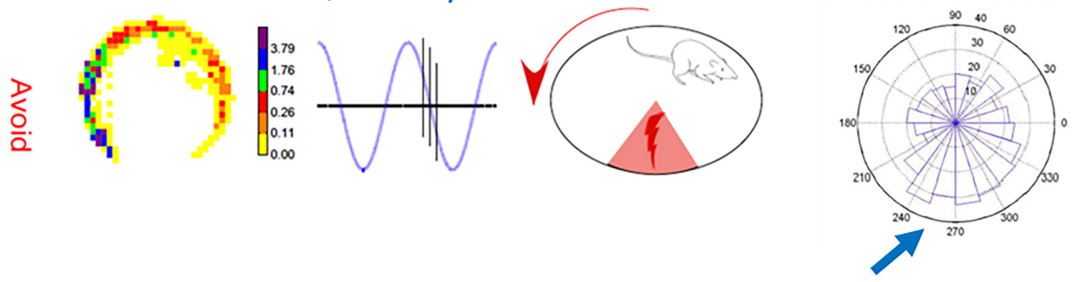

Figure 1. Place cell AP phase preference with regard to local $\theta$. (A) AP firing rate map with median firing rate per pixel for a single place cell. $(B)$ Phase map indicating the median phase of $\theta$ for APs in each pixel. (C) Rose plot circular histogram indicating the place cell's preferred firing phase with $\theta$. The phase map in $B$ indicates that the APs tend to fire earlier in the $\theta$ cycle as the animal moves through the firing field. The higher firing rates correspond to phases between $240^{\circ}-320^{\circ}$ (arrow), consistent with the rose plot in $C$. (D) Shift in preferred phase of firing of a hippocampal place cell within the $\theta$ cycle between foraging and avoidance contexts. During foraging the cell fired in the ascending phase of $\theta$. During active avoidance session the cell shifted firing to the descending phase of $\theta$. Rose plot histogram demonstrates a shift of phase preference from $\sim 150^{\circ}$ in foraging to $\sim 240^{\circ}-270^{\circ}$ in active avoidance (arrows).

and segregation of neuronal assemblies necessary for spatial memory (Winson 1978; Buzsáki 2002; Gupta et al. 2012) and is present in rat pups during the first week of life (Karlsson and Blumberg 2003). Spatial cognition processing is also dependent on $\gamma$ oscillations, rhythmic fluctuations in local field potentials (LFPs) that span a broad range of frequencies $(25-100 \mathrm{~Hz}$ ) (Colgin and Moser 2010) and are present in the first week of life (Quilichini et al. 2012). Two functionally distinct rhythms, slow $(25-50 \mathrm{~Hz})$ and fast (55-100 Hz) $\gamma$ (Colgin et al. 2009; Colgin 2016) are present in the hippocampus. These different frequencies of $\gamma$ rhythms are thought to be locally generated by GABAergic interneurons (Colgin 2016; Mably and Colgin 2018). While slow and fast $\gamma$ are locally generated, $\gamma$ oscillators exhibiting similar frequencies in different brain regions can become coupled by anatomical connections between structures (Mably and Colgin 2018). Fast $\gamma$ rhythms in the hippocampus are coupled with fast $\gamma$ inputs from the mEC (Colgin et al. 2009). Fast $\gamma(50-140 \mathrm{~Hz})$ reflects entorhinal cortex-CA1 circuit innervation and contributes to memory encoding (Colgin et al. 2009; Colgin 2015, 2016) while slow $\gamma(25-50 \mathrm{~Hz})$ reflects CA3-CA1 circuit innervation and contributes to memory retrieval (Colgin et al. 2009; Colgin 2016).

In addition to $\theta$ and $\gamma$ oscillations, a major network oscillation pattern in the hippocampus are "sharp waves and ripples" (SWRs). SWRs are large amplitude $(0.5-1.5 \mathrm{mV})$ negative polarity field potentials with a duration of $40-100$ msec occurring in the CA1 stratums radiatum (Buzsáki 1986). SWRs emerge at the end of the second postnatal week in rats (Buhl and Buzsáki 2005). The sharp waves are usually associated with a short-lived fast oscillatory pattern fast-field oscillations ( 140 to $200 \mathrm{~Hz}$ ), so-called "ripples" confined to the CA1 cell layer (O'Keefe and Nadel 1978; Buzsáki et al. 1992; Traub et al. 2000). SWRs are endogenous events that specific network architectures supporting the production of appropriate receptive fields are generated. Two main mechanisms participate in assembling neuronal networks. First, the expression of specific ligands and receptors guides axons and dendrites to their innervation territories, and promote the formation of synapses (Stoeckli 2018). Second, stereotyped patterns of activity propagate through developing circuits to refine cell-to-cell functional connectivity (Stryker and Harris 1986; Kirkby et al. 2013). The combination of these two processes-finding the proper partners and giving rise to networks that can efficiently process informationmake spatial cognition possible.

The mechanisms underlying the assembly of neural circuits have been extensively studied for sensory systems, especially those devoted to vision. Here, axons from ganglion cells take an intricate route to leave the retina and reach specific territories of the thalamus and the superior colliculus (Godement et al. 1984). In turn, thalamic axons follow their own intricate path to reach a specific portion of the cortical anlage, what will become the primary visual cortex (Parnavelas and Chatzissavidou 1981). A series of attractant or repulsive signals guide these axons toward their specific targets; Robo/Slit, NrCam, Netrins, Ephs and ephrins, and many other molecules have been implicated in this process (Brittis et al. 1995; Brown et al. 2000; Erskine et al. 2000; Afari et al. 2014; Erskine and Herrera 2014). This elegant process is not sufficient on its own to produce the sophisticated network architecture that supports vision. To create an internal representation of the sensory space, the visual system is designed to allow for an accurate representation of the visual scene. Specifically, two visual inputs that are nearby in space and stimulate proximate portions of the retina, are represented by neighboring cells in multiple areas of the visual system giving rise to a coherent topographical map of 
the stimulus (Schuett et al. 2002). Connections between neighboring cells must therefore be strengthened, while connections between cells that are located further away from each other must be weakened. To achieve this aim, intrinsically generated patterns of activity cross the sensory areas like "waves" to optimize the synaptic matrix of the network for the representation of visual stimuli (Meister et al. 1991; Wong et al. 1995; Katz and Shatz 1996; Ackman et al. 2012; Kirkby et al. 2013). The fact that sensory organs dominate the initiation of these waves, which propagate through the nervous system to reach the neocortex (Ackman et al. 2012), suggest that the sensory receptor-bearing cells drive the maturation of extended neural networks devoted to sensory perception.

As neural ensembles move further and further away from the sensory organ, topographic organization is not evident and receptive fields arise because of locally produced computations. The mEC-hippocampal system is one such network. Located at a great synaptic distance from sensory epithelia, this network sits on top of the cortical hierarchy and integrates multisensory stimuli to produce cell types whose firing is coded to specific locations of the environment or aspects of navigation. The mEC creates a neural representation of space through a set of functionally dedicated cell types: grid cells, border cells, head direction cells, and speed cells (Felleman and Van Essen 1991; van Strien et al. 2009; Rowland et al. 2016) with the rate of maturation unique to each type of neuron (Tan et al. 2017). Grid cells first emerge around P21 and develop functional properties rapidly. As soon as grid cells can be detected, they possess almost all of the properties that characterize adult grid cell firing (Wills et al. 2012). Individual grid cells may mature over the course of approximately $1 \mathrm{~d}$. At P22-23, the percentage of mEC cells classified as grid cells reaches a similar level to adults (Wills et al. 2010). Furthermore, in vitro recordings show that mEC stellate cell network synchronization significantly increases at P22 (Langston et al. 2010). This suggests that the widespread recurrent excitatory network thought to be necessary for grid cell activity emerges at this age (Fuhs and Touretzky 2006; McNaughton et al. 2006; Burak and Fiete 2009).

While the first adult-like grid cells are present at weaning, place cells show spatially tuned and stable firing at least $4 \mathrm{~d}$ earlier at $\sim$ P16 (Langston et al. 2010; Wills et al. 2010). Before weaning, offline place cell activity replay with SWRs reflects predominantly stationary locations in recently visited environments. The place cell representation of space is denser, more stable, and more accurately close to environmental boundaries. A putative stabilizing signal to place cells before grid cells emerge are boundary-responsive cells. mEC boundary cells emerge at P17 and drive stable place cell firing before weaning (Wills et al. 2010; Bjerknes et al. 2014). In contrast, sequential place cell firing, describing extended trajectories through space during exploration ( $\theta$ sequences) and subsequent rest (replay), emerge gradually after weaning in a coordinated fashion (Muessig et al. 2019). This developmental switch in place cell accuracy coincides with the emergence of the grid cell network in the mEC, suggesting that grid cells contribute to stable place fields when an animal is far from environmental boundaries (Muessig et al. 2015). This developmental switch in place accuracy also coincides with the development of allocentric spatial memory in rodents. Figures 2 and 3 provide schematics showing timing of development of key factors involved in spatial memory and the relationship between EC and hippocampal cells and oscillatory activity.

The mechanisms that produce spatially tuned firing patterns are still unknown, but likely rely on the interplay between the hippocampus and the $\mathrm{mEC}$. Silencing one part of the network severely affects spatial representations produced by the other (Bonnevie et al. 2013). Based on these premises, it is proposed that the spatially tuned firing of grid and place cells arises from local com-

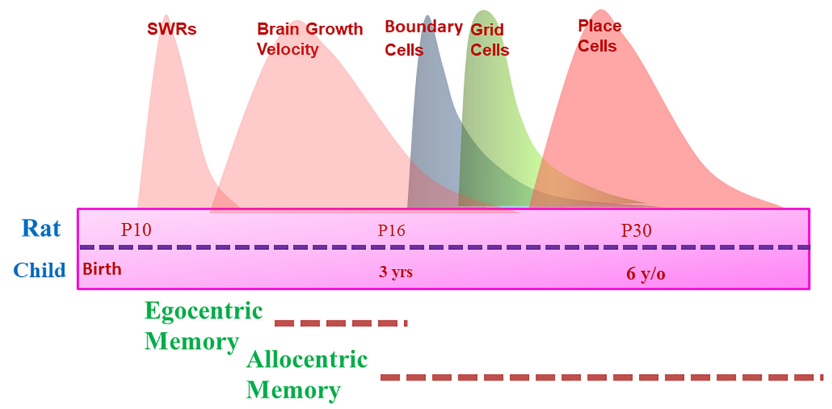

Figure 2. Schematic showing timing of development of key factors involved in spatial memory. As boundary, grid and place cells develop there is a transition from egocentric to allocentric memory.

putations as a result of the specific synaptic architecture of the network (Martin and Berthoz 2002; McNaughton et al. 2006; Couey et al. 2013; Moser et al. 2014). Furthermore, it has been hypothesized that patterned activity propagating through the mEC-hippocampal circuit during a sensitive developmental phase finely tunes synaptic connectivity of the network, and drives the emergence of specific firing patterns (McNaughton et al. 2006; Kropff and Treves 2008). As described above, the firing patterns of grid and place cells evolve and mature during postnatal development (Langston et al. 2010; Wills et al. 2010; Scott et al. 2011; Muessig et al. 2015).

Multiple molecular signals are involved in setting up connectivity across the areas that belong to the mEC-hippocampal network. Cells located in the mEC establish their projections to the hippocampus during embryonic life. mEC axons can be backlabelled from the hippocampus by embryonic (E) day15 and innervate the dentate gyrus by E18 (Supèr and Soriano 1994). To reach their destination, mEC fibers use a scaffold that is created by Cajal-Retzius cells located in the hippocampus. These cells create a "trail" on which EC axons can grow and provide the substrate on which mEC axons can make synaptic contacts (Ceranik et al. 1999). The commissural axons originating from the hippocampal subfields are formed later, between E18 and P2 (Supèr and Soriano 1994) and use a plethora of molecular signals (including Semaphorins, Neuropilin, Slits, and Ephrins [see Skutella and Nitsch 2001]) to find their targets. However, due to a protracted period of neurogenesis and synaptogenesis that extends into postnatal life, reaching an adult-like level at the end of childhood (Deguchi et al. 2011; Donato et al. 2017), the connectivity matrix of the mEC-hippocampal network reorganizes extensively during the first postnatal month. During the same period, excitability influences synaptogenesis in each hippocampal subfields (JohnsonVenkatesh et al. 2015), with patterned activity being generated at multiple stages of the network (Garaschuk et al. 2000; Leinekugel et al. 2002; Crépel et al. 2007).

Correlated activity in the mEC-hippocampal neuronal networks, supported by oscillatory and intermittent population activity patterns is critical for learning and memory. However, when and how correlated activity emerges in these networks during development remains largely unknown. During the first postnatal week in nonanaesthetized head-restrained rats, activity in the superficial layers of the mEC and hippocampus is highly correlated, with intermittent population bursts in the mEC followed by early SWRs in the hippocampus (Valeeva et al. 2018). Neurons in the superficial mEC layers fired before neurons in the dentate gyrus, CA3 and CA1. Current-source density profiles of early SWRs indicate that performant path and temporoammonic entorhinal inputs and intrinsic hippocampal connections are coactivated during mEC-hippocampal activity bursts. Most mEC-hippocampal 


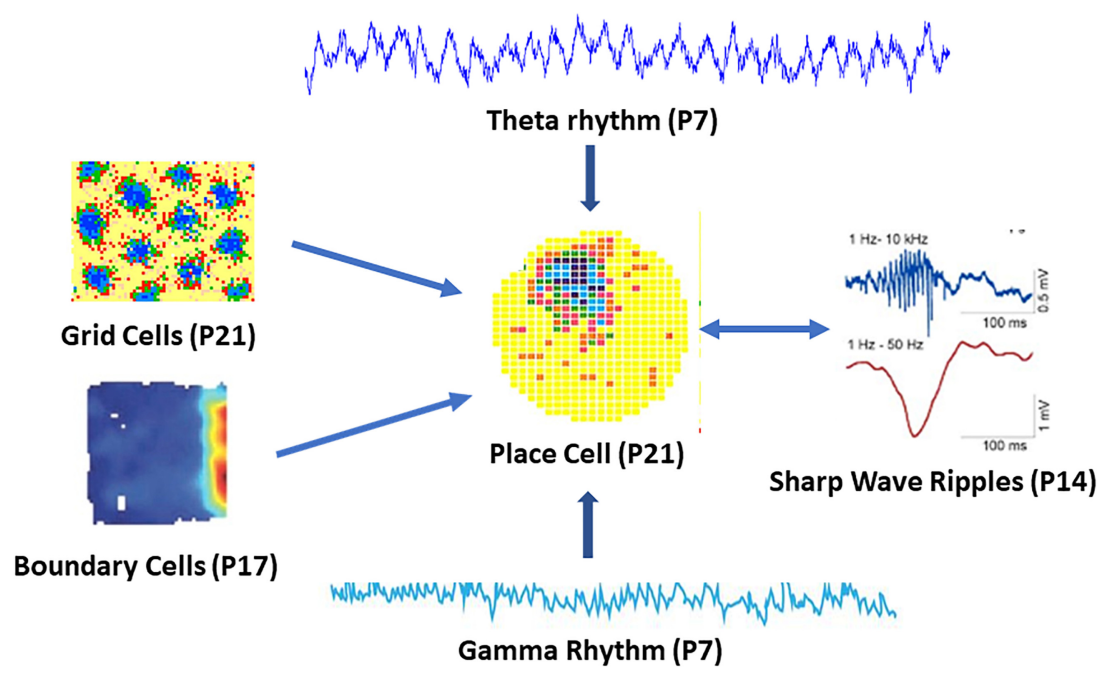

Figure 3. Schematic showing relationship between place cells and EC cells and oscillations. $m E C$ boundary cells emerge at P17 and drive stable place cell firing before weaning. Grid cells emerge by P21 and stabilize place cells away from boundaries resulting in allocentric navigation. $\theta$ and $\gamma$ activity, which are present in the first postnatal week, add the dimension of temporal coding to place cell firing. During sharp wave ripples which are present by the second postnatal week result in replay of APs during sleep or awake states. activity drives the maturation of downstream areas of the network in a linear and directional developmental sequence. This sequence originates in mEC layer 2 , where maturation of stellate cells precedes that of other excitatory cell types in the circuit. Silencing stellate cells arrests the maturation of excitatory and inhibitory neurons at every stage of the mEC-hippocampal network; in stark contrast, silencing pyramidal cells did not. This leads to the conclusion that stellate cells in mEC drives the maturation of the mEC-hippocampal network. The stellate cells are the source of an activitydependent signal that propagates stagewise through the network to promote structural maturation of excitatory and inhibitory neurons. Whereas the excitatory actions in the mEC-hippocampus drives synaptic development and connectivity, it is important to note that excessive excitability can be detrimental to developing neural circuits, as will be described below. bursts are triggered by spontaneous myoclonic body movements. Thus, during the neonatal period, activity in the mEC and hippocampus is highly synchronous, with the mEC leading to hippocampal activation. It is proposed that such correlated activity is embedded into a large-scale bottom-up circuit that processes somatosensory feedback resulting from neonatal movements, and that it is likely to instruct the development of connections between neocortex and hippocampus. Indeed, a similar process has been proposed for the development of the somatosensory circuit (Khazipov et al. 2004). In rat pups, spatially confined spindle bursts are selectively triggered in a somatotopic manner by spontaneous muscle twitches, motor patterns analogous to human fetal movements (Khazipov et al. 2004).

Important questions arising from these findings pertain to how excitatory activity influence the maturation of the mEChippocampal system. Maturation of the mEC-hippocampal network follows a stereotyped sequence, where layer 2 of the $\mathrm{mEC}$ is the first area to mature, followed by CA3, CA1, dentate gyrus, subiculum, layer 5 of the mEC and layer 2 of the lateral EC (Fig. 4; Donato et al. 2017). At each stage of the circuit, excitatory

\section{Disruptions of developing networks supporting spatial memory in rodents}

As noted above, there is a precise timing of developmental events that depend on genetic and activity-dependent mechanism to assure normal connectivity of the brain leading to normal spatial cognition. Recent evidence has indicated there is a critical period for processing memories which depends on activity and plasticity mechanisms within the developing hippocampus (Travaglia et al. $2016 a, b)$. For example, the activity-regulated and memory-linked gene Arc/Arg3.1 is transiently up-regulated in the hippocampus during the first postnatal month. Conditional removal of Arc/ Arg3.1 during this period permanently alters hippocampal oscillations and diminishes spatial learning capacity throughout adulthood (Gao et al. 2018). In contrast, post developmental removal of Arc/Arg3.1 leaves learning and network activity patterns intact. Long-term memory storage continues to rely on Arc/Arg3.1 expression throughout life. These results indicate there are critical period for spatial learning, during which Arc/Arg3.1 foster maturation of hippocampal network activity necessary for future learning and
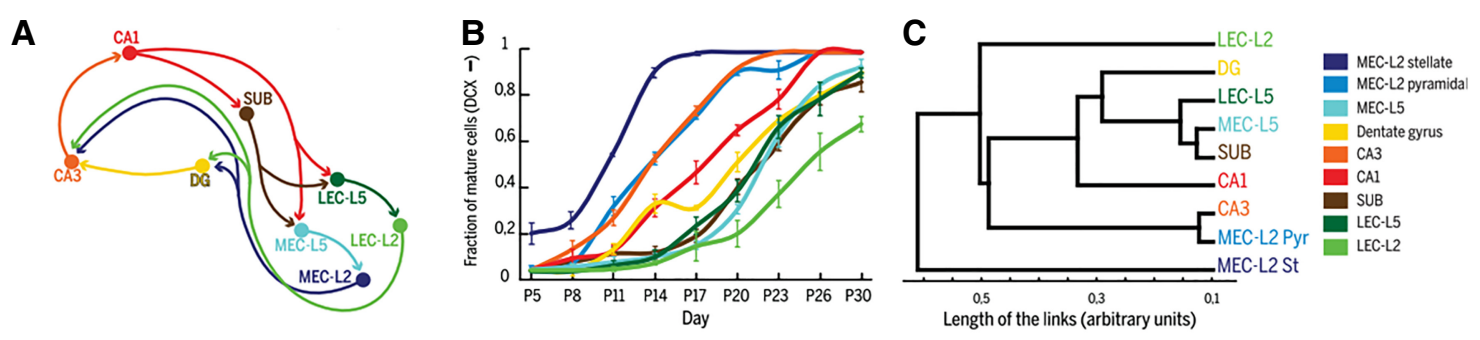

Figure 4. Stagewise sequential maturation of the entorhinal-hippocampal network (Donato et al. 2017). (A) Schematic representation of information flow in the transverse entorhinal-hippocampal circuit. $(B)$ Fraction of neurons with doublecortin (DCX) expression levels below the detection limit in each local network during successive days of maturation (DCX cumulative distributions, means $\pm S D$ ). DCX is a microtubule-associated protein that is present in neuronal precursors and immature neurons, where it promotes dendritic growth and is down-regulated during the stabilization of synaptic connectivity at late developmental stages. (C) Hierarchical clustering of data in $(B) ; x$-axis length of the links of the dendrogram, arbitrary units. $\mathrm{mEC}$ layer $(\mathrm{L}) 2$ striatal cells (MEC-L2 St) are the first population to exhibit dissimilarity from the rest of the network, followed by (i) MEC-L2 pyramidal (Pyr) and CA3, (ii) CA1, (iii) dentate gyrus, subiculum (SUB), MEC-L5, and LEC-L5, and (iv) LEC-L2. 
memory storage. These critical principles of memory network development and maturation are fundamental to our understanding of how aberrant activity patterns early in life may lead to disrupted structural and functional maturation of the same circuits.

There are multiple pathological conditions that can disrupt the normal development of spatial memory. Genetic causes such as Fragile $\mathrm{X}$, Rett syndrome and Angelman syndrome can result in maldevelopment of networks serving spatial cognition (Dan et al. 2015). The Ube3a mouse model of Angelman syndrome, the Ts65Dn trisomy mouse model of Down syndrome, the FXS model of Fragile X syndrome and the Mecp2Bird mouse model of Rett syndrome have demonstrated deficits in spatial cognition (Gomi et al. 2010; Sun et al. 2016; Leach and Crawley 2018). Acquired insults such as hypoxia, trauma or infections can also produce pronounced deficits in spatial cognition. The mechanisms of these disruptions vary depending on the genetic or acquired insult involved. Here, we focus on the role of aberrant activity during critical developmental period in provoking enduring memory problems. We focus on a clinically relevant type of aberrant network activity: the synchronized bursts of massive numbers of neurons that fire together during seizures.

Whereas normal activity patterns are required for circuit maturation, aberrant neuronal activity is known to disrupt spatial cognition (Davis et al. 2017). This is particularly important in the case of massive bursts of synchronized network activity which occur during seizures. The effects of seizures on the development and integrity of memory circuits is of major clinical relevance; one of the more common neurological conditions in children is epilepsy. Although seizures are the most striking clinical manifestation of the epilepsies, children with epilepsy are at risk not only for seizures but also for a myriad of comorbid health problems that occur at a higher rate than would be expected by chance. Among the comorbidities associated with childhood epilepsy, memory disturbances are among the most common and troublesome (Hermann et al. 2002; Holmes 2015).

Seizures associated with fever in children, when longer than 30 min (termed febrile status epilepticus or FSE), can lead to epilepsy that involves the hippocampal circuit (temporal lobe epilepsy). Importantly, recent work in children (Weiss et al. 2017) has identified memory problems in children who sustained FSE even before the onset of epilepsy, suggesting that memory functions and the underlying circuits were directly impacted by the FSE.

To probe the causal relationship of FSE and memory problems, and uncover the mechanisms, an experimental FSE (eFSE) model has been created and heavily adopted and validated (Dubé et al. 2000, 2012; Dubé and Baram 2006; McClelland et al. 2011). eFSE is generated by elevating brain temperature to $38^{\circ} \mathrm{C}-29^{\circ} \mathrm{C}$, temperatures generating seizures in children. The hyperthermia is needed because induction of fever is not possible in infant rats (Dubé et al. 2007), though some elevation of brain temperature using lipopolysaccharide administration has been described (Heida et al. 2009). Notably, inflammatory cytokines are induced and are involved in these febrile-like seizures (Dubé et al. 2005; Vezzani et al. 2011a). To mimic childhood FSE, hyperthermia is maintained for $\sim 60 \mathrm{~min}$, resulting in seizures lasting 40-50 min. eFSE is generated via hyperthermia, because induction of fever is not possible in infant rats (Dubé et al. 2007). However, inflammatory cytokines are induced and are involved in these febrile-like seizures (Dubé et al. 2005; Vezzani et al. 2011a,b). To mimic childhood FSE, hyperthermia is maintained for $\sim 60 \mathrm{~min}$, resulting in seizures lasting 40-50 min. These seizures provoke memory deficits during adolescence and in adulthood, including, notably, impaired spatial cognition (Dubé et al. 2006, 2009; Barry et al. 2016a,b; Patterson et al. 2017). Importantly, no cell loss occurs following eFSE, yet neuronal structure in hippocampus is affected, including dendrite loss in CA1 and aberrant generation of excitato- ry synapses in dentate gyrus granule cells (Patterson et al. 2017). The presence of spatial memory and structural deficits after eFSE provides a unique opportunity to study how aberrant patterns of network activity during development disrupt the maturation of memory networks.

Spatial cognition following eFSE is tested in the active avoidance task, a systems-level task where animals learn to associate an unmarked region of space with a mild shock on a constantly rotating arena (Baglietto et al. 2001; Pastalkova et al. 2006; Popp et al. 2011; Barry et al. 2015, 2016a). Control rats rapidly learn the spatial location of the shock-zone using spatial cues which surround the rotating arena, whereas eFSE rats received significantly more shocks than controls, suggesting that they are not able to effectively learn and remember the location of the shock quadrant. A second measure of spatial learning in this task is the time spent in the quadrant opposite the shock zone, indicating a spatial strategy used to avoid shocks. eFSE rats spend significantly less time in the opposite quadrant as compared to controls, suggesting that these animals used a less efficient, potentially nonspatial strategy to avoid shocks (Barry et al. 2016a).

These memory problems are associated with clear electrophysiological aberrations of the network (Patterson et al. 2017). Following eFSE, speed/ $\theta$ correlations ( $\theta$ frequency normally increases with speed of running) are reduced dramatically. Both fast and slow $\gamma$ frequency and amplitude were abnormal in eFSE rats and correlated with learning and memory deficits. In aggregate, the findings indicate that the balance of routed neural information to CA1 from the EC (fast $\gamma$ ) and CA3 (slow $\gamma$ ) is disrupted by eFSE, interfering with both the acquisition of spatial information believed to be associated with mEC inputs and the recall of information believed to be associated with CA3-CA1 input.

Following eFSE there are also abnormalities in temporal coding (Barry et al. 2016a). As shown in Figure 5, during foraging, which does not require hippocampal involvement, CA1 place cells from controls fire near the peak of local $\theta$, whereas during active avoidance, which is a hippocampal-dependent task, the CA1 cells fire at later phase of $\theta$ that is more in register with a static $\theta$ phase preference in CA3 (Barry et al. 2016a). The population of CA1 place cells from eFSE rats do not exhibit a preferred phase of firing during either foraging and active avoidance. Phase coupling, that is the coordinated firing of APs in CA3 and CA1 at the same phase of $\theta$, is thus greater in the controls than in the eFSE rats. Both the absence of phase preference in CA1 and inability to shift phase preference to align APs in both CA3 and CA1 circuits during a hippocampaldependent task, indicate neuronal discoordination provoked by the eFSE. Insufficient coordination between structures in the hippocampal circuit by $\theta$ oscillations prevent the eFSE rats from accurately calculating their position during the active avoidance task.

The molecular mechanisms by which early-life seizures lead to disruptions at the cellular and network levels are emerging. Recently, it was discovered that eFSE provokes coordinated, transcriptionally regulated changes in the expression of a relatively small set of genes governing neuronal behavior. These changes result from augmented function of the neuron-restrictive silencing factor (NRSF), which is uniquely situated among numerous brain transcription factors to mediate neuronal plasticity after eFSE (McClelland et al. 2011, 2014; Patterson et al. 2017) due to its unique role in neuronal maturation and in the function of mature neurons. NRSF expression was originally described in nonneuronal tissues where it suppresses neuron-specific genes (Schoenherr and Anderson 1995; Chen et al. 1998). This role predicted that many neuronal genes must carry NRSF-response elements (NRSEs) and will therefore be repressed by augmented NRSF (McClelland et al. 2014). Recently, low levels of NRSF however expression in mature neurons has been described, where the factor may be crucial for normal function (Ballas et al. 2005; Ballas and Mandel 2005; Gao 


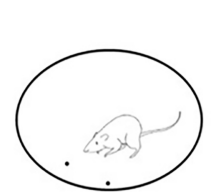

Foraging

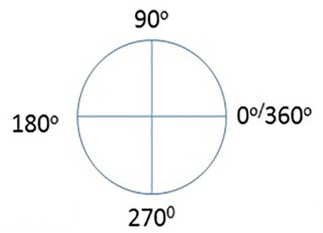

$270^{\circ}$
CTL

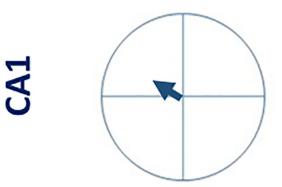

$\mathrm{p}=0.003$

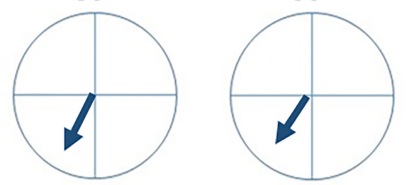

$p<0.0001$

\section{$p<0.0001$}

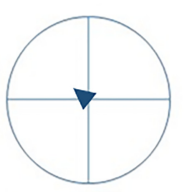

$p>0.05$

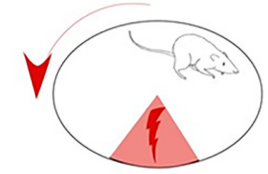

Active Avoidance $\stackrel{m}{5}$

Figure 5. Distribution of preferred firing phases for place cells recorded during foraging sessions in CA1 (Top) and CA3 (Bottom) from control (CTL) and eFSE animals. CTL CA1 cells showed a significant phase preference at $214^{\circ}$ while eFSE cells had a mean, nonsignificant, phase angle preference of $194^{\circ}$. CTL CA3 cells had a significant phase preference toward the descending phase of $\theta\left(257^{\circ}\right)$ as did eFSE animals $\left(226^{\circ}\right.$ ). During active avoidance CTL CA1 cells significantly shifted phase preference to the descending phase of $\Theta$ at $260^{\circ}$ while eFSE CA1 cells exhibited a lack of phase preference. CTL CA1 phase preference shifts away from peak $\Theta$ puts cell firing preference in CA1 and CA3 in alignment. et al. 2011). Tight regulation of NRSF levels is especially crucial to developing neurons, where expression of NRSF-regulated genes contributes to several aspects of maturation, including development of excitatory synapses (Schoenherr and Anderson 1995; Chen et al. 1998; Yang et al. 2012). This is important because FSE takes place during the developmental epoch (infancy and early childhood in humans, P10-11 in the rat (AvishaiEliner et al. 2002), when many brain neurons are largely mature but when specific neuronal populations, including granule cells in the dentate gyrus, are still differentiating and maturing (Schlessinger et al. 1975; Thind et al. 2008).

NRSF activity is dramatically augmented after eFSE, leading to repression of a number of important genes, such as those coding for ion channels, glutamate receptors, synaptic proteins, and others (McClelland et al. 2014; Brennan et al. 2016). To test directly if NRSF-overactivity contributed to the disruption of memory circuits provoked by eFSE NRSF function was blocked through use of deoxyoligonucleotides (ODNs) which binds to NRSF and prevents it from reaching and binding the DNA of target genes (Patterson et al. 2017). Hippocampal
A

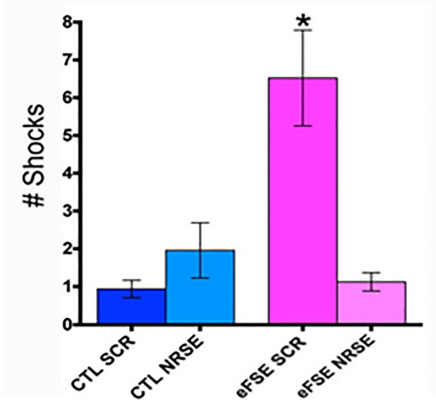

B

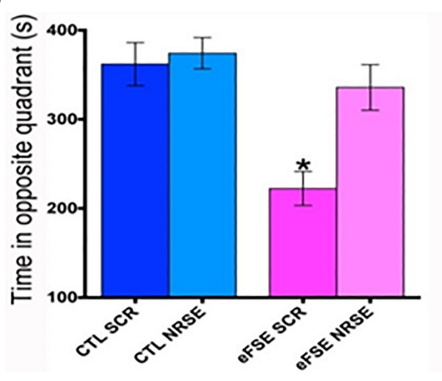

C
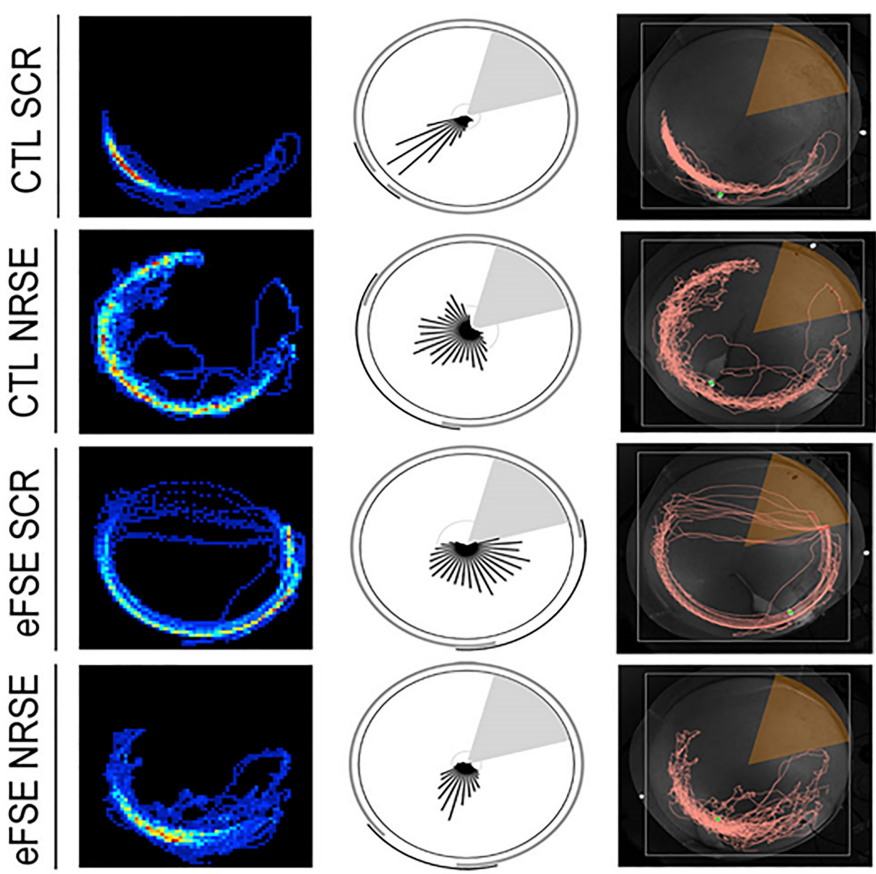

Figure 6. eFSE provokes persistent impairment of spatial memory in active avoidance which is abrogated by blocking NRSF after eFSE (Patterson et al. 2017). (A) eFSE rats treated with a SCR ODN received more shocks than both control groups (CTL + SCR ODN, CTL + NRSE ODN), as well as from eFSE rats treated post hoc with a blocker of NRSF (eFSE + NRSE ODN). (B) Similar results are obtained when assessing the duration of time spent in the opposite quadrant to the shock zone. The eFSE + SCR group spent less time in the opposite quadrant than the other three groups. (C) Representative traces of movement of rats from each of the four groups. 
network oscillatory activity and temporal coding during active avoidance testing was then assessed in young adult rats that had experienced eFSE. Notably, the administration of specific NRSE ODN prevented the spatial deficits seen in eFSE rats. The memory performance of rats receiving NRSE ODN was indistinguishable from the controls in the active avoidance task (Fig. 6). Rats receiving scrambled ODN, which consist of ODNs that do not block NRSE and thus serve as a control injection, had spatial deficits following the eFSE.

NRSF blockade following eFSE also enhanced slow $\gamma$ oscillations and prevented abnormalities in speed/ $\theta$ correlation coefficients (Patterson et al. 2017), in parallel to restoring memory function. Blocking NRSF also rescued the structural maturation of dentate gyrus granule cells. Thus, blocking NRSF transiently after eFSE prevented granule cell dysmaturation, restores a functional balance of $\gamma$-band network oscillations, and allows treated eFSE rats to encode and retrieve spatial memories. Together, this work provides novel insights into both the normal construction of networks that underlie memory as well as the mechanisms by which earlylife seizures in rodents disrupt this maturation. While it is unlikely that ODNs will be used to treat children with FSE, understanding the molecular signaling that results in spatial cognitive deficits provides a roadmap to exciting future therapeutics.

\section{Conclusions}

In children, allocentric spatial memory emerges around 22 mo of age whereas in rats allocentric spatial memory develops between P20-P25. Allocentric spatial memory in rats coincide with the functional maturation of place cells. The developmental switch in place cell accuracy coincides with the emergence of the grid cell network in the EC, and mechanistic studies indicate that grid cells contribute to stable place fields. The ontogeny of spatial memory in rodents is highly orchestrated and includes sensitive periods during which axons and dendrites need to establish appropriate connections that optimize information processing. The molecular signals responsible for these developing networks are increasing being identified. Whereas normal activity patterns are required for circuit maturation, there is now evidence that abnormal neuronal activity-including seizures-can disrupt this process resulting in aberrant connectivity and impaired signaling, manifesting as deficits in spatial cognition. Understanding the molecular and cellular bases for this disrupted maturation holds promise for preventative and therapeutic interventions.

\section{Acknowledgments}

This work was supported by the National Institutes of Health (NIH) Grants NS108765 (G.L.H.); NS108296 (G.L.H.,T.Z.B.); NS35439; MH73136 (T.Z.B.).

\section{References}

Ackman JB, Burbridge TJ, Crair MC. 2012. Retinal waves coordinate patterned activity throughout the developing visual system. Nature 490: 219-225. doi:10.1038/nature11529

Afari ME, Blum AS, Mernoff ST, Ott BR. 2014. Driving policy after seizures and unexplained syncope: a practice guide for RI physicians. R I Med J (2013) 97: 40-43.

Amaral DG, Dent JA. 1981. Development of the mossy fibers of the dentate gyrus: I. A light and electron microscopic study of the mossy fibers and their expansions. J Comp Neurol 195: 51-86. doi:10.1002/cne .901950106

Avishai-Eliner S, Brunson KL, Sandman CA, Baram TZ. 2002. Stressed-out, or in (utero)? Trends Neurosci 25: 518-524. doi:10.1016/S0166-2236(02) 02241-5

Babiloni F, Babiloni C, Fattorini L, Carducci F, Onorati P, Urbano A. 1995. Performances of surface Laplacian estimators: a study of simulated and real scalp potential distributions. Brain Topogr 8: 35-45. doi:10.1007/ BF01187668

Baglietto MG, Battaglia FM, Nobili L, Tortorelli S, De NE, Calevo MG, Veneselli E, De NM. 2001. Neuropsychological disorders related to interictal epileptic discharges during sleep in benign epilepsy of childhood with centrotemporal or Rolandic spikes. Dev Med Child Neurol 43: 407-412. doi:10.1017/S0012162201000755

Ballas N, Mandel G. 2005. The many faces of REST oversee epigenetic programming of neuronal genes. Curr Opin Neurobiol 15: 500-506. doi:10.1016/j.conb.2005.08.015

Ballas N, Grunseich C, Lu DD, Speh JC, Mandel G. 2005. REST and its corepressors mediate plasticity of neuronal gene chromatin throughout neurogenesis. Cell 121: 645-657. doi:10.1016/j.cell.2005.03.013

Banta Lavenex PA, Colombo F, Ribordy Lambert F, Lavenex P. 2014. The human hippocampus beyond the cognitive map: evidence from a densely amnesic patient. Front Hum Neurosci 8: 711. doi:10.3389/fnhum .2014.00711

Barry JM, Choy M, Dubé C, Robbins A, Obenaus A, Lenck-Santini PP, Scott RC, Baram TZ, Holmes GL. 2015. T2 relaxation time post febrile status epilepticus predicts cognitive outcome. Exp Neurol 269: 242-252. doi:10.1016/j.expneurol.2015.04.015

Barry JM, Sakkaki S, Barriere SJ, Patterson KP, Lenck-Santini PP, Scott RC, Baram TZ, Holmes GL. 2016a. Temporal coordination of hippocampal neurons reflects cognitive outcome post-febrile status epilepticus. EBioMedicine 7: 175-190. doi:10.1016/j.ebiom.2016.03.039

Barry JM, Tian C, Spinella A, Page M, Holmes GL. 2016b. Spatial cognition following early-life seizures in rats: performance deficits are dependent on task demands. Epilepsy Behav 60: 1-6. doi:10.1016/j.yebeh.2016.03 .032

Bauer PJ. 2008. Toward a neuro-developmental account of the development of declarative memory. Dev Psychobiol 50: $19-31$. doi:10.1002/dev .20265

Bjerknes TL, Moser EI, Moser MB. 2014. Representation of geometric borders in the developing rat. Neuron 82: 71-78. doi:10.1016/j.neuron.2014.02 .014

Bonnevie T, Dunn B, Fyhn M, Hafting T, Derdikman D, Kubie JL, Roudi Y, Moser EI, Moser MB. 2013. Grid cells require excitatory drive from the hippocampus. Nat Neurosci 16: 309-317. doi:10.1038/nn.3311

Brankačk J, Stewart M, Fox SE. 1993. Current source density analysis of the hippocampal $\theta$ rhythm: associated sustained potentials and candidate synaptic generators. Brain Res 615: 310-327. doi:10.1016/0006-8993 (93)90043-M

Bremner JG, Knowles L, Andreasen G. 1994. Processes underlying young children's spatial orientation during movement. J Exp Child Psychol 57: 355-376. doi:10.1006/jecp.1994.1017

Brennan GP, Dey D, Chen Y, Patterson KP, Magnetta EJ, Hall AM, Dubé CM, Mei YT, Baram TZ. 2016. Dual and opposing roles of microRNA-124 in epilepsy are mediated through inflammatory and NRSF-dependent gene networks. Cell Rep 14: 2402-2412. doi:10.1016/j.celrep.2016.02.042

Brittis PA, Lemmon V, Rutishauser U, Silver J. 1995. Unique changes of ganglion cell growth cone behavior following cell adhesion molecule perturbations: a time-lapse study of the living retina. Mol Cell Neurosci 6: 433-449. doi:10.1006/mcne.1995.1032

Brown RW, Kraemer PJ. 1997. Ontogenetic differences in retention of spatial learning tested with the Morris water maze. Dev Psychobiol 30: 329-341. doi:10.1002/(SICI)1098-2302(199705)30:4<329::AID-DEV6>3.0.CO ;2-Q

Brown A, Yates PA, Burrola P, Ortuño D, Vaidya A, Jessell TM, Pfaff SL, O'Leary DD, Lemke G. 2000. Topographic mapping from the retina to the midbrain is controlled by relative but not absolute levels of EphA receptor signaling. Cell 102: 77-88. doi:10.1016/S0092-8674(00) 00012-X

Buhl DL, Buzsáki G. 2005. Developmental emergence of hippocampal fast-field "ripple" oscillations in the behaving rat pups. Neuroscience 134: 1423-1430. doi:10.1016/j.neuroscience.2005.05.030

Bunsey M, Eichenbaum H. 1996. Conservation of hippocampal memory function in rats and humans. Nature 379: 255-257. doi:10.1038/ $379255 \mathrm{aO}$

Burak Y, Fiete IR. 2009. Accurate path integration in continuous attractor network models of grid cells. PLoS Comput Biol 5: e1000291. doi:10 .1371/journal.pcbi.1000291

Bushnell EW, McKenzie BE, Lawrence DA, Connell S. 1995. The spatial coding strategies of one-year-old infants in a locomotor search task. Child Dev 66: 937-958. doi:10.2307/1131790

Buzsáki G. 1986. Hippocampal sharp waves: their origin and significance. Brain Res 398: 242-252. doi:10.1016/0006-8993(86)91483-6

Buzsáki G. 2002. $\theta$ oscillations in the hippocampus. Neuron 33: 325-340. doi:10.1016/S0896-6273(02)00586-X

Buzsáki G, Leung LW, Vanderwolf CH. 1983. Cellular basis of hippocampal EEG in the behaving rat. Brain Res 287: 139-171. doi:10.1016/ 0165-0173(83)90037-1 
Buzsáki G, Horvath Z, Urioste R, Hetke J, Wise K. 1992. High-frequency network oscillation in the hippocampus. Science 256: 1025-1027. doi:10 .1126/science.1589772

Ceranik K, Deng J, Heimrich B, Lübke J, Zhao S, Förster E, Frotscher M. 1999. Hippocampal Cajal-Retzius cells project to the entorhinal cortex: retrograde tracing and intracellular labelling studies. Eur J Neurosci 11: 4278-4290. doi:10.1046/j.1460-9568.1999.00860.x

Chen ZF, Paquette AJ, Anderson DJ. 1998. NRSF/REST is required in vivo for repression of multiple neuronal target genes during embryogenesis. Nat Genet 20: $136-142$. doi: $10.1038 / 2431$

Colgin LL. 2015. Do slow and fast $\gamma$ rhythms correspond to distinct functional states in the hippocampal network? Brain Res 1621: 309-315. doi:10.1016/j.brainres.2015.01.005

Colgin LL. 2016. Rhythms of the hippocampal network. Nat Rev Neurosci 17: 239-249. doi:10.1038/nrn.2016.21

Colgin LL, Moser EI. 2010. $\gamma$ oscillations in the hippocampus. Physiology (Bethesda) 25: 319-329.

Colgin LL, Denninger T, Fyhn M, Hafting T, Bonnevie T, Jensen O, Moser MB, Moser EI. 2009. Frequency of $\gamma$ oscillations routes flow of information in the hippocampus. Nature 462: 353-357. doi:10.1038/ nature08573

Collie R, Hayne H. 1999. Deferred imitation by 6- and 9-month-old infants: more evidence for declarative memory. Dev Psychobiol 35: 83-90. doi:10 .1002/(SICI)1098-2302(199909)35:2<83::AID-DEV1>3.0.CO;2-S

Couey JJ, Witoelar A, Zhang SJ, Zheng K, Ye J, Dunn B, Czajkowski R, Moser MB, Moser EI, Roudi Y, et al. 2013. Recurrent inhibitory circuitry as a mechanism for grid formation. Nat Neurosci 16: 318-324. doi:10 $.1038 / \mathrm{nn} .3310$

Crépel V, Aronov D, Jorquera I, Represa A, Ben-Ari Y, Cossart R. 2007. A parturition-associated nonsynaptic coherent activity pattern in the developing hippocampus. Neuron 54: 105-120. doi:10.1016/j.neuron .2007 .03 .007

Crowley K, Trinder J, Kim Y, Carrington M, Colrain IM. 2002. The effects of normal aging on sleep spindle and K-complex production. Clin Neurophysiol 113: 1615-1622. doi:10.1016/S1388-2457(02)00237-7

Crystal JD, Smith AE. 2014. Binding of episodic memories in the rat. Curr Biol 24: 2957-2961. doi:10.1016/j.cub.2014.10.074

Dan B, Pelc K, de Meirleir L, Cheron G. 2015. Phenotypic plasticity and the perception-action-cognition-environment paradigm in

neurodevelopmental genetic disorders. Dev Med Child Neurol 57: 52-54. doi:10.1111/dmcn.12694

Davis EP, Stout SA, Molet J, Vegetabile B, Glynn LM, Sandman CA, Heins K, Stern H, Baram TZ. 2017. Exposure to unpredictable maternal sensory signals influences cognitive development across species. Proc Natl Acad Sci 114: 10390-10395. doi:10.1073/pnas.1703444114

Deguchi Y, Donato F, Galimberti I, Cabuy E, Caroni P. 2011. Temporally matched subpopulations of selectively interconnected principal neurons in the hippocampus. Nat Neurosci 14: 495-504. doi:10.1038/nn .2768

Dolorfo CL, Amaral DG. 1998a. Entorhinal cortex of the rat: organization of intrinsic connections. J Comp Neurol 398: 49-82. doi:10.1002/(SICI) 1096-9861(19980817)398:1<49::AID-CNE4>3.0.CO;2-9

Dolorfo CL, Amaral DG. 1998b. Entorhinal cortex of the rat: topographic organization of the cells of origin of the perforant path projection to the dentate gyrus. J Comp Neurol 398: 25-48. doi:10.1002/(SICI)1096-9861 (19980817)398:1<25::AID-CNE3>3.0.CO;2-B

Donato F, Jacobsen RI, Moser MB, Moser EI. 2017. Stellate cells drive maturation of the entorhinal-hippocampal circuit. Science 355: eaai8178. doi:10.1126/science.aai8178

Dragoi G, Buzsáki G. 2006. Temporal encoding of place sequences by hippocampal cell assemblies. Neuron 50: 145-157. doi:10.1016/j .neuron.2006.02.023

Dubé CM, Baram TZ. 2006. Complex febrile seizures-an experimental model in immature rodents. In Models of seizures and epilepsy, (ed. Pitkänen A, Schwartzkroin PA, Moshé S), pp. 333-340. Elsevier, Burlington, Massachusetts.

Dubé C, Chen K, Eghbal-Ahmadi M, Brunson K, Soltesz I, Baram TZ. 2000. Prolonged febrile seizures in the immature rat model enhance hippocampal excitability long term. Ann Neurol 47: 336-344. doi:10 .1002/1531-8249(200003)47:3<336::AID-ANA9>3.0.CO;2-W

Dubé C, Vezzani A, Behrens M, Bartfai T, Baram TZ. 2005. Interleukin-1 $\beta$ contributes to the generation of experimental febrile seizures. Ann Neurol 57: 152-155. doi:10.1002/ana.20358

Dubé C, Richichi C, Bender RA, Chung G, Litt B, Baram TZ. 2006. Temporal lobe epilepsy after experimental prolonged febrile seizures: prospective analysis. Brain 129: 911-922. doi:10.1093/brain/awl018

Dubé CM, Brewster AL, Richichi C, Zha Q, Baram TZ. 2007. Fever, febrile seizures and epilepsy. Trends Neurosci 30: 490-496. doi:10.1016/j.tins 2007.07.006

Dubé CM, Zhou JL, Hamamura M, Zhao Q, Ring A, Abrahams J, McIntyre K, Nalcioglu O, Shatskih T, Baram TZ, et al. 2009. Cognitive dysfunction after experimental febrile seizures. Exp Neurol 215: 167-177. doi:10 .1016/j.expneurol.2008.10.003

Dubé CM, McClelland S, Choy MK, Brewster AL, Noam Y, Baram TZ. 2012. Fever, febrile seizures and epileptogenesis. In Jasper's Basic Mechanisms of the Epilepsies [Internet], 4th edn (ed. Noebels JL, Avoli M, Rogawski MA, Olsen RW, Delgado-Escueta AV). National Center for Biotechnology Information, Bethesda, MD.

Dupret D, O’Neill J, Pleydell-Bouverie B, Csicsvari J. 2010. The reorganization and reactivation of hippocampal maps predict spatial memory performance. Nat Neurosci 13: 995-1002. doi:10.1038/nn.2599

Ego-Stengel V, Wilson MA. 2010. Disruption of ripple-associated hippocampal activity during rest impairs spatial learning in the rat. Hippocampus 20: 1-10. doi:10.1002/hipo.20707

Eichenbaum H, Cohen NJ. 2014. Can we reconcile the declarative memory and spatial navigation views on hippocampal function? Neuron 83: 764 770. doi:10.1016/j.neuron.2014.07.032

Eichenbaum H, Dudchenko P, Wood E, Shapiro M, Tanila H. 1999. The hippocampus, memory, and place cells: is it spatial memory or a memory space? Neuron 23: 209-226. doi:10.1016/S0896-6273(00) 80773-4

Erskine L, Herrera E. 2014. Connecting the retina to the brain. ASN Neuro 6: 1759091414562107. doi:10.1177/1759091414562107

Erskine L, Williams SE, Brose K, Kidd T, Rachel RA, Goodman CS, Tessier-Lavigne M, Mason CA. 2000. Retinal ganglion cell axon guidance in the mouse optic chiasm: expression and function of robos and slits. J Neurosci 20: 4975-4982. doi:10.1523/JNEUROSCI .20-13-04975.2000

Felleman DJ, Van Essen DC. 1991. Distributed hierarchical processing in the primate cerebral cortex. Cereb cortex 1: 1-47. doi:10.1093/cercor/1.1.1

Fenton AA, Kao HY, Neymotin SA, Olypher A, Vayntrub Y, Lytton WW, Ludvig N. 2008. Unmasking the CA1 ensemble place code by exposures to small and large environments: more place cells and multiple, irregularly arranged, and expanded place fields in the larger space. $J$ Neurosci 28: 11250-11262. doi:10.1523/JNEUROSCI.2862-08.2008

Fogel SM, Smith CT. 2011. The function of the sleep spindle: a physiological index of intelligence and a mechanism for sleep-dependent memory consolidation. Neurosci Biobehav Rev 35: 1154-1165. doi:10.1016/j neubiorev.2010.12.003

Fuhs MC, Touretzky DS. 2006. A spin glass model of path integration in rat medial entorhinal cortex. J Neurosci 26: 4266-4276. doi:10.1523/ JNEUROSCI.4353-05.2006

Fyhn M, Hafting T, Treves A, Moser MB, Moser EI. 2007. Hippocampal remapping and grid realignment in entorhinal cortex. Nature 446: 190 194. doi:10.1038/nature05601

Gao Z, Ure K, Ding P, Nashaat M, Yuan L, Ma J, Hammer RE, Hsieh J. 2011. The master negative regulator REST/NRSF controls adult neurogenesis by restraining the neurogenic program in quiescent stem cells. J Neurosci 31: 9772-9786. doi:10.1523/JNEUROSCI.1604-11.2011

Gao X, Castro-Gomez S, Grendel J, Graf S, Süsens U, Binkle L, Mensching D, Isbrandt D, Kuhl D, Ohana O. 2018. Arc/Arg3.1 mediates a critical period for spatial learning and hippocampal networks. Proc Natl Acad Sci 115: 12531-12536. doi:10.1073/pnas.1810125115

Garaschuk O, Linn J, Eilers J, Konnerth A. 2000. Large-scale oscillatory calcium waves in the immature cortex. Nat Neurosci 3: 452-459. doi:10 $.1038 / 74823$

Girardeau G, Benchenane K, Wiener SI, Buzsáki G, Zugaro MB. 2009. Selective suppression of hippocampal ripples impairs spatial memory. Nat Neurosci 12: 1222-1223. doi:10.1038/nn.2384

Godement P, Salaün J, Imbert M. 1984. Prenatal and postnatal development of retinogeniculate and retinocollicular projections in the mouse. $J$ Comp Neurol 230: 552-575. doi:10.1002/cne.902300406

Gomi H, Sassa T, Thompson RF, Itohara S. 2010. Involvement of cyclin-dependent kinase-like 2 in cognitive function required for contextual and spatial learning in mice. Front Behav Neurosci 4: 17. doi:10.3389/fnbeh.2010.00017

Gupta AS, van der Meer MA, Touretzky DS, Redish AD. 2012. Segmentation of spatial experience by hippocampal $\theta$ sequences. Nat Neurosci 15: 1032-1039. doi:10.1038/nn.3138

Hafting T, Fyhn M, Molden S, Moser MB, Moser EI. 2005. Microstructure of a spatial map in the entorhinal cortex. Nature 436: 801-806. doi:10.1038/ nature 03721

Hasselmo ME. 2005. What is the function of hippocampal $\theta$ rhythm?Linking behavioral data to phasic properties of field potential and unit recording data. Hippocampus 15: 936-949. doi:10.1002/hipo.20116

Hasselmo ME, Stern CE. 2014. $\theta$ rhythm and the encoding and retrieval of space and time. Neuroimage 85: 656-666. doi:10.1016/j.neuroimage .2013 .06 .022

Hayne H, Herbert J. 2004. Verbal cues facilitate memory retrieval during infancy. J Exp Child Psychol 89: 127-139. doi:10.1016/j.jecp.2004.06 002

Hayne H, Imuta K. 2011. Episodic memory in 3- and 4-year-old children. Dev Psychobiol 53: 317-322. doi:10.1002/dev.20527 
Hayne H, Rovee-Collier C. 1995. The organization of reactivated memory in infancy. Child Dev 66: 893-906. doi:10.2307/1131957

Hayne H, Rovee-Collier C, Perris EE. 1987. Categorization and memory retrieval by three-month-olds. Child Dev 58: 750-767. doi:10.2307/ 1130212

Hayne H, Rovee-Collier C, Borza MA. 1991. Infant memory for place information. Mem Cogn 19: 378-386. doi:10.3758/BF03197142

Heida JG, Moshé SL, Pittman QJ. 2009. The role of interleukin-1 $\beta$ in febrile seizures. Brain Dev 31: 388-393. doi:10.1016/j.braindev.2008.11.013

Hermann BP, Seidenberg M, Bell B. 2002. The neurodevelopmental impact of childhood onset temporal lobe epilepsy on brain structure and function and the risk of progressive cognitive effects. Prog Brain Res 135: 429-438. doi:10.1016/S0079-6123(02)35040-4

Hok V, Lenck-Santini PP, Roux S, Save E, Muller RU, Poucet B. 2007. Goal-related activity in hippocampal place cells. J Neurosci 27: 472-482. doi:10.1523/JNEUROSCI.2864-06.2007

Holmes GL. 2015. Cognitive impairment in epilepsy: the role of network abnormalities. Epileptic Disord 17: 101-116.

Hoscheidt SM, Nadel L, Payne J, Ryan L. 2010. Hippocampal activation during retrieval of spatial context from episodic and semantic memory. Behav Brain Res 212: 121-132. doi:10.1016/j.bbr.2010.04.010

Hyman JM, Wyble BP, Goyal V, Rossi CA, Hasselmo ME. 2003. Stimulation in hippocampal region CA1 in behaving rats yields long-term potentiation when delivered to the peak of $\theta$ and long-term depression when delivered to the trough. J Neurosci 23: 11725-11731. doi:10.1523/ JNEUROSCI.23-37-11725.2003

Johnson-Venkatesh EM, Khan MN, Murphy GG, Sutton MA, Umemori H. 2015. Excitability governs neural development in a hippocampal region-specific manner. Development 142: 3879-3891. doi:10.1242/dev .121202

Josselyn SA, Frankland PW. 2012. Infantile amnesia: a neurogenic hypothesis. Learn Mem 19: 423-433. doi:10.1101/lm.021311.110

Kamondi A, Acsády L, Wang XJ, Buzsáki G. 1998. $\theta$ oscillations in somata and dendrites of hippocampal pyramidal cells in vivo: activity-dependent phase-precession of action potentials. Hippocampus 8: 244-261.<244::AID-HIPO7>3.0.CO;2-J

Karlsson KA, Blumberg MS. 2003. Hippocampal $\theta$ in the newborn rat is revealed under conditions that promote REM sleep. J Neurosci 23: 11141118. doi:10.1523/JNEUROSCI.23-04-01114.2003

Katz LC, Shatz CJ. 1996. Synaptic activity and the construction of cortical circuits. Science 274: 1133-1138. doi:10.1126/science.274.5290.1133

Khazipov R, Sirota A, Leinekugel X, Holmes GL, Ben-Ari Y, Buzsáki G. 2004. Early motor activity drives spindle bursts in the developing somatosensory cortex. Nature 432: 758-761. doi:10.1038/nature03132

Kirkby LA, Sack GS, Firl A, Feller MB. 2013. A role for correlated spontaneous activity in the assembly of neural circuits. Neuron 80: 1129-1144. doi:10 $.1016 /$ j.neuron.2013.10.030

Kleen JK, Testorf ME, Roberts DW, Scott RC, Jobst BJ, Holmes GL, Lenck-Santini PP. 2016. Oscillation phase locking and late ERP components of intracranial hippocampal recordings correlate to patient performance in a working memory task. Front Hum Neurosci 10: 287. doi:10.3389/fnhum.2016.00287

Knierim JJ, Neunuebel JP, Deshmukh SS. 2014. Functional correlates of the lateral and medial entorhinal cortex: objects, path integration and local-global reference frames. Philos Trans R Soc Lond B Biol Sci 369: 20130369. doi:10.1098/rstb.2013.0369

Kretschmann HJ, Kammradt G, Krauthausen I, Sauer B, Wingert F. 1986. Growth of the hippocampal formation in man. Bibl Anat 28: 27-52.

Kropff E, Treves A. 2008. The emergence of grid cells: intelligent design or just adaptation? Hippocampus 18: 1256-1269. doi:10.1002/hipo.20520

Kwag J, Paulsen O. 2009. The timing of external input controls the sign of plasticity at local synapses. Nat Neurosci 12: 1219-1221. doi:10.1038/nn 2388

Langston RF, Ainge JA, Couey JJ, Canto CB, Bjerknes TL, Witter MP, Moser EI, Moser MB. 2010. Development of the spatial representation system in the rat. Science 328: 1576-1580. doi:10.1126/science.1188210

Lavenex P, Banta LP. 2013. Building hippocampal circuits to learn and remember: insights into the development of human memory. Behav Brain Res 254: 8-21. doi:10.1016/j.bbr.2013.02.007

Leach PT, Crawley JN. 2018. Touchscreen learning deficits in Ube3a, Ts65Dn and Mecp 2 mouse models of neurodevelopmental disorders with intellectual disabilities. Genes Brain Behav 17: e12452. doi:10.1111/gbb .12452

Lee AK, Wilson MA. 2002. Memory of sequential experience in the hippocampus during slow wave sleep. Neuron 36: 1183-1194. doi:10 $.1016 /$ S0896-6273(02)01096-6

Leinekugel X, Khazipov R, Cannon R, Hirase H, Ben-Ari Y, Buzsáki G. 2002. Correlated bursts of activity in the neonatal hippocampus in vivo. Science 296: 2049-2052. doi:10.1126/science.1071111

Lenck-Santini PP, Holmes GL. 2008. Altered phase precession and compression of temporal sequences by place cells in epileptic rats. $J$ Neurosci 28: 5053-5062. doi:10.1523/JNEUROSCI.5024-07.2008
Lenck-Santini PP, Save E, Poucet B. 2001. Evidence for a relationship between place-cell spatial firing and spatial memory performance. Hippocampus 11: 377-390. doi:10.1002/hipo.1052

Lenck-Santini PP, Muller RU, Save E, Poucet B. 2002. Relationships between place cell firing fields and navigational decisions by rats. J Neurosci 22: 9035-9047. doi:10.1523/JNEUROSCI.22-20-09035.2002

Lew AR, Bremner JG, Lefkovitch LP. 2000. The development of relational landmark use in six- to twelve-month-old infants in a spatial orientation task. Child Dev 71: 1179-1190. doi:10.1111/1467-8624.00222

Mably AJ, Colgin LL. 2018. $\gamma$ oscillations in cognitive disorders. Curr Opin Neurobiol 52: 182-187. doi:10.1016/j.conb.2018.07.009

Marshall PJ, Bar-Haim Y, Fox NA. 2002. Development of the EEG from 5 months to 4 years of age. Clin Neurophysiol 113: 1199-1208. doi:10 1016/S1388-2457(02)00163-3

Martin PD, Berthoz A. 2002. Development of spatial firing in the hippocampus of young rats. Hippocampus 12: 465-480. doi:10.1002/ hipo. 10021

Martin N, Lafortune M, Godbout J, Barakat M, Robillard R, Poirier G, Bastien C, Carrier J. 2013. Topography of age-related changes in sleep spindles. Neurobiol Aging 34: 468-476. doi:10.1016/j.neurobiolaging .2012 .05 .020

McClain IJ, Lustenberger C, Achermann P, Lassonde JM, Kurth S, LeBourgeois MK. 2016. Developmental changes in sleep spindle characteristics and sigma power across early childhood. Neural Plast 2016: 3670951 . doi: $10.1155 / 2016 / 3670951$

McClelland S, Flynn C, Dubé C, Richichi C, Zha Q, Ghestem A, Esclapez M, Bernard C, Baram TZ. 2011. Neuron-restrictive silencer factor-mediated hyperpolarization-activated cyclic nucleotide gated channelopathy in experimental temporal lobe epilepsy. Ann Neurol 70: 454-464. doi:10 $.1002 /$ ana.22479

McClelland S, Brennan GP, Dubé C, Rajpara S, Iyer S, Richichi C, Bernard C, Baram TZ. 2014. The transcription factor NRSF contributes to epileptogenesis by selective repression of a subset of target genes. Elife $\mathbf{3}$ : e01267. doi:10.7554/eLife.01267

McNamara CG, Tejero-Cantero A, Trouche S, Campo-Urriza N, Dupret D. 2014. Dopaminergic neurons promote hippocampal reactivation and spatial memory persistence. Nat Neurosci 17: 1658-1660. doi:10.1038/ nn. 3843

McNaughton BL, Battaglia FP, Jensen O, Moser EI, Moser MB. 2006. Path integration and the neural basis of the 'cognitive map'. Nat Rev Neurosci 7: 663-678. doi:10.1038/nrn1932

Meister M, Wong RO, Baylor DA, Shatz CJ. 1991. Synchronous bursts of action potentials in ganglion cells of the developing mammalian retina. Science 252: 939-943. doi:10.1126/science.2035024

Morris RGM. 1981. Spatial localization does not require the presence of local cues. Learn Motiv 12: 239-260. doi:10.1016/0023-9690(81)90020-5

Moser EI, Roudi Y, Witter MP, Kentros C, Bonhoeffer T, Moser MB. 2014. Grid cells and cortical representation. Nat Rev Neurosci 15: 466-481. doi:10.1038/nrn3766

Moser MB, Rowland DC, Moser EI. 2015. Place cells, grid cells, and memory. Cold Spring Harb Perspect Biol 7: a021808. doi:10.1101/cshperspect .a021808

Muessig L, Hauser J, Wills TJ, Cacucci F. 2015. A developmental switch in place cell accuracy coincides with grid cell maturation. Neuron 86: 11671173. doi:10.1016/j.neuron.2015.05.011

Muessig L, Lasek M, Varsavsky I, Cacucci F, Wills TJ. 2019. Coordinated emergence of hippocampal replay and $\theta$ sequences during post-natal development. Curr Biol 29: 834-840.e4. doi:10.1016/j.cub.2019.01.005

Mullally SL, Maguire EA. 2014. Learning to remember: the early ontogeny of episodic memory. Dev Cogn Neurosci 9: 12-29. doi:10.1016/j.den.2013 .12 .006

Muller R. 1996. A quarter of a century of place cells. Neuron 17: 813-822. doi:10.1016/S0896-6273(00)80214-7

Nádasdy Z, Hirase H, Czurkó A, Csicsvari J, Buzsáki G. 1999. Replay and time compression of recurring spike sequences in the hippocampus. J Neurosci 19: 9497-9507. doi:10.1523/JNEUROSCI.19-21-09497.1999

Newcombe NS, Lloyd ME, Ratliff KR. 2007. Development of episodic and autobiographical memory: a cognitive neuroscience perspective. $A d v$ Child Dev Behav 35: 37-85. doi:10.1016/B978-0-12-009735-7.50007-4

Nicolas A, Petit D, Rompré S, Montplaisir J. 2001. Sleep spindle characteristics in healthy subjects of different age groups. Clin Neurophysiol 112: 521-527. doi:10.1016/S1388-2457(00)00556-3

Nunez PL, Westdorp AF. 1994. The surface Laplacian, high resolution EEG and controversies. Brain Topogr 6: 221-226. doi:10.1007/BF01187712

O'Keefe J. 1973. Place units in the hippocampus of freely moving rats. Exp Neurol 51: 78-109. doi:10.1016/0014-4886(76)90055-8

O'Keefe J, Dostrovsky J. 1971. The hippocampus as a spatial map: preliminary evidence from unit activity in the freely-moving rat. Brain Res 34: 171-175. doi:10.1016/0006-8993(71)90358-1

O'Keefe J, Nadel L. 1978. The Hippocampus as a Cognitive Map. Clarendon, Oxford. 
O'Keefe J, Burgess N, Donnett JG, Jeffery KJ, Maguire EA. 1998. Place cells, navigational accuracy, and the human hippocampus. Philos Trans $R$ Soc Lond B Biol Sci 353: 1333-1340. doi:10.1098/rstb.1998.0287

Parnavelas JG, Chatzissavidou A. 1981. The development of the thalamic projections to layer I of the visual cortex of the rat. Anat Embryol (Berl) 163: 71-75. doi:10.1007/BF00315771

Pastalkova E, Serrano P, Pinkhasova D, Wallace E, Fenton AA, Sacktor TC. 2006. Storage of spatial information by the maintenance mechanism of LTP. Science 313: 1141-1144. doi:10.1126/science.1128657

Patterson KP, Barry JM, Curran MM, Singh-Taylor A, Brennan G, Rismanchi N, Page M, Noam Y, Holmes GL, Baram TZ. 2017. Enduring memory impairments provoked by developmental febrile seizures are mediated by functional and structural effects of neuronal restrictive silencing factor. J Neurosci 37: 3799-3812. doi:10.1523/JNEUROSCI $.3748-16.2017$

Popp SS, Lei B, Kelemen E, Fenton AA, Cottrell JE, Kass IS. 2011. Intravenous antiarrhythmic doses of lidocaine increase the survival rate of CA1 neurons and improve cognitive outcome after transient global cerebral ischemia in rats. Neuroscience 192: 537-549. doi:10.1016/j.neuroscience .2011 .06 .086

Quilichini PP, Le Van Quyen M, Ivanov A, Turner DA, Carabalona A, Gozlan H, Esclapez M, Bernard C. 2012. Hub GABA neurons mediate $\gamma$-frequency oscillations at ictal-like event onset in the immature hippocampus. Neuron 74: 57-64. doi:10.1016/j.neuron.2012.01.026

Ribak CE, Seress L, Amaral DG. 1985. The development, ultrastructure and synaptic connections of the mossy cells of the dentate gyrus. J Neurocytol 14: $835-857$. doi:10.1007/BF01170832

Ribordy F, Jabes A, Banta LP, Lavenex P. 2013. Development of allocentric spatial memory abilities in children from 18 months to 5 years of age. Cogn Psychol 66: 1-29. doi:10.1016/j.cogpsych.2012.08.001

Ribordy F, Lambert F, Lavenex P, Banta LP. 2017. The "when" and the "where" of single-trial allocentric spatial memory performance in young children: Insights into the development of episodic memory. Dev Psychobiol 59: 185-196. doi:10.1002/dev.21479

Rossier J, Schenk F. 2003. Olfactory and/or visual cues for spatial navigation through ontogeny: olfactory cues enable the use of visual cues. Behav Neurosci 117: 412-425. doi:10.1037/0735-7044.117.3.412

Rovee-Collier C, Hayne H. 1987. Reactivation of infant memory: implications for cognitive development. Adv Child Dev Behav 20: 185 238. doi:10.1016/S0065-2407(08)60403-6

Rovee-Collier CK, Sullivan MW, Enright M, Lucas D, Fagen JW. 1980. Reactivation of infant memory. Science 208: 1159-1161. doi:10.1126/ science. 7375924

Rovee-Collier C, Patterson J, Hayne H. 1985. Specificity in the reactivation of infant memory. Dev Psychobiol 18: 559-574. doi:10.1002/dev .420180611

Rowland DC, Roudi Y, Moser MB, Moser EI. 2016. Ten Years of Grid Cells. Аnпи Rev Neurosci 39: 19-40. doi:10.1146/ annurev-neuro-070815-013824

Rudy JW, Stadler-Morris S, Albert P. 1987. Ontogeny of spatial navigation behaviors in the rat: dissociation of "proximal"- and "distal"-cue-based behaviors. Behav Neurosci 101: 62-73. doi:10.1037/0735-7044.101.1.62

Sargolini F, Fyhn M, Hafting T, McNaughton BL, Witter MP, Moser MB, Moser EI. 2006. Conjunctive representation of position, direction, and velocity in entorhinal cortex. Science 312: 758-762. doi:10.1126/science .1125572

Satterthwaite TD, Elliott MA, Ruparel K, Loughead J, Prabhakaran K, Calkins ME, Hopson R, Jackson C, Keefe J, Riley M, et al. 2014. Neuroimaging of the Philadelphia neurodevelopmental cohort. Neuroimage 86: 544-553. doi:10.1016/j.neuroimage.2013.07.064

Scarf D, Gross J, Colombo M, Hayne H. 2013. To have and to hold: episodic memory in 3- and 4-year-old children. Dev Psychobiol 55: 125-132. doi:10.1002/dev.21004

Schenk F. 1985. Development of place navigation in rats from weaning to puberty. Behav Neural Biol 43: 69-85. doi:10.1016/S0163-1047(85) 91510-9

Schlessinger AR, Cowan WM, Gottlieb DI. 1975. An autoradiographic study of the time of origin and the pattern of granule cell migration in the dentate gyrus of the rat. J Comp Neurol 159: 159-176. doi:10.1002/cne .901590202

Schoenherr CJ, Anderson DJ. 1995. The neuron-restrictive silencer factor (NRSF): a coordinate repressor of multiple neuron-specific genes. Science 267: 1360-1363. doi:10.1126/science.7871435

Schuett S, Bonhoeffer T, Hübener M. 2002. Mapping retinotopic structure in mouse visual cortex with optical imaging. J Neurosci 22: 6549-6559. doi:10.1523/JNEUROSCI.22-15-06549.2002

Scott RC, Richard GR, Holmes GL, Lenck-Santini PP. 2011. Maturational dynamics of hippocampal place cells in immature rats. Hippocampus 21: 347-353. doi:10.1002/hipo.20789

Scoville WB, Milner B. 1957. Loss of recent memory after bilateral hippocampal lesions. J Neurol Neurosurg Psychiatry 20: 11-20. doi:10 $.1136 /$ jnnp.20.1.11
Seress L, Mrzljak L. 1992. Postnatal development of mossy cells in the human dentate gyrus: a light microscopic Golgi study. Hippocampus 2: 127-141. doi:10.1002/hipo.450020205

Seress L, Ribak CE. 1995. Postnatal development and synaptic connections of hilar mossy cells in the hippocampal dentate gyrus of rhesus monkeys. J Comp Neurol 355: 93-110. doi:10.1002/cne.903550111

Sheperd GM, Grillner S. 2018. Handbook of brain microcircuits. Oxford University Press, Oxford, UK.

Shibagaki M, Kiyono S, Watanabe K. 1982. Spindle evolution in normal and mentally retarded children: a review. Sleep 5: 47-57. doi:10.1093/sleep/5 .1 .47

Shrager Y, Kirwan CB, Squire LR. 2008. Neural basis of the cognitive map: path integration does not require hippocampus or entorhinal cortex. Proc Natl Acad Sci 105: 12034-12038. doi:10.1073/pnas.0805414105

Siegle JH, Wilson MA. 2014. Enhancement of encoding and retrieval functions through $\theta$ phase-specific manipulation of hippocampus. Elife 3: e03061. doi:10.7554/eLife.03061

Sjolund LA, Kelly JW, McNamara TP. 2018. Optimal combination of environmental cues and path integration during navigation. Mem Cogn 46: 89-99. doi:10.3758/s13421-017-0747-7

Skaggs WE, McNaughton BL. 1996. Replay of neuronal firing sequences in rat hippocampus during sleep following spatial experience. Science 271: 1870-1873. doi:10.1126/science.271.5257.1870

Skaggs WE, McNaughton BL, Wilson MA, Barnes CA. 1996. $\theta$ phase precession in hippocampal neuronal populations and the compression of temporal sequences. Hippocampus 6: 149-172. doi:10.1002/(SICI) 1098-1063(1996)6:2<149::AID-HIPO6>3.0.CO;2-K

Skutella T, Nitsch R. 2001. New molecules for hippocampal development. Trends Neurosci 24: 107-113. doi:10.1016/S0166-2236(00)01717-3

Sporns O, Chialvo DR, Kaiser M, Hilgetag CC. 2004. Organization, development and function of complex brain networks. Trends Cogn Sci 8: 418-425. doi:10.1016/j.tics.2004.07.008

Squire LR. 1986. Mechanisms of memory. Science 232: 1612-1619. doi:10 $.1126 /$ science.3086978

Squire LR, Zola-Morgan S. 1985. The neuropsychology of memory: new links between humans and experimental animals. Ann N Y Acad Sci 444: 137-149. doi:10.1111/j.1749-6632.1985.tb37585.x

Squire LR, Zola-Morgan S. 1988. Memory: brain systems and behavior. Trends Neurosci 11: 170-175. doi:10.1016/0166-2236(88)90144-0

Squire LR, Zola-Morgan S, Cave CB, Haist F, Musen G, Suzuki WA. 1990. Memory: organization of brain systems and cognition. Cold Spring Harb Symp Quant Biol 55: 1007-1023. doi:10.1101/SQB.1990.055.01.096

Stoeckli ET. 2018. Understanding axon guidance: are we nearly there yet? Development 145: dev151415. doi:10.1242/dev.151415

Stryker MP, Harris WA. 1986. Binocular impulse blockade prevents the formation of ocular dominance columns in cat visual cortex. J Neurosci 6: 2117-2133. doi:10.1523/JNEUROSCI.06-08-02117.1986

Sun MK, Hongpaisan J, Alkon DL. 2016. Rescue of synaptic phenotypes and spatial memory in young fragile X mice. J Pharmacol Exp Ther 357: 300310. doi:10.1124/jpet.115.231100

Supèr H, Soriano E. 1994. The organization of the embryonic and early postnatal murine hippocampus. II. Development of entorhinal, commissural, and septal connections studied with the lipophilic tracer DiI. J Comp Neurol 344: 101-120. doi:10.1002/cne.903440108

Tan HM, Wills TJ, Cacucci F. 2017. The development of spatial and memory circuits in the rat. Wiley Interdiscip Rev Cogn Sci 8. doi:10.1002/wcs.1424

Taylor MJ, Donner EJ, Pang EW. 2012. fMRI and MEG in the study of typical and atypical cognitive development. Neurophysiol Clin 42: 19-25. doi:10 $.1016 / j$. neucli.2011.08.002

Thind KK, Ribak CE, Buckmaster PS. 2008. Synaptic input to dentate granule cell basal dendrites in a rat model of temporal lobe epilepsy. J Comp Neurol 509: 190-202. doi:10.1002/cne.21745

Traub RD, Bibbig A, Fisahn A, LeBeau FE, Whittington MA, Buhl EH. 2000. A model of $\gamma$-frequency network oscillations induced in the rat CA3 region by carbachol in vitro. Eur J Neurosci 12: 4093-4106. doi:10.1046/j $.1460-9568.2000 .00300 . \mathrm{x}$

Travaglia A, Bisaz R, Cruz E, Alberini CM. 2016a. Developmental changes in plasticity, synaptic, glia and connectivity protein levels in rat dorsal hippocampus. Neurobiol Learn Mem 135: 125-138. doi:10.1016/j.nlm .2016 .08 .005

Travaglia A, Bisaz R, Sweet ES, Blitzer RD, Alberini CM. 2016b. Infantile amnesia reflects a developmental critical period for hippocampal learning. Nat Neurosci 19: 1225-1233. doi:10.1038/nn.4348

Valeeva G, Janackova S, Nasretdinov A, Rychkova V, Makarov R, Holmes GL, Khazipov R, Lenck-Santini PP. 2018. Emergence of coordinated activity in the developing entorhinal-hippocampal network. Cereb Cortex 29: 906-920. doi:10.1093/cercor/bhy309

van Strien NM, Cappaert NL, Witter MP. 2009. The anatomy of memory: an interactive overview of the parahippocampal-hippocampal network. Nat Rev Neurosci 10: 272-282. doi:10.1038/nrn2614

Vezzani A, French J, Bartfai T, Baram TZ. 2011a. The role of inflammation in epilepsy. Nat Rev Neurol 7: 31-40. doi:10.1038/nrneurol.2010.178 
Vezzani A, Maroso M, Balosso S, Sanchez MA, Bartfai T. 2011b. IL-1 receptor/ Toll-like receptor signaling in infection, inflammation, stress and neurodegeneration couples hyperexcitability and seizures. Brain Behav Immun 25: 1281-1289. doi:10.1016/j.bbi.2011.03.018

Vorhees CV, Williams MT. 2014. Assessing spatial learning and memory in rodents. ILAR J 55: 310-332. doi:10.1093/ilar/ilu013

Wallace DG, Gorny B, Whishaw IQ. 2002a. Rats can track odors, other rats, and themselves: implications for the study of spatial behavior. Behav Brain Res 131: 185-192. doi:10.1016/S0166-4328(01) 00384-9

Wallace DG, Hines DJ, Pellis SM, Whishaw IQ. 2002b. Vestibular information is required for dead reckoning in the rat. J Neurosci 22: 10009-10017. doi:10.1523/JNEUROSCI.22-22-10009.2002

Weiss EF, Masur D, Shinnar S, Hesdorffer DC, Hinton VJ, Bonner M, Rinaldi J, Van dW V, Culbert J, Shinnar RC, et al. 2017. Memory function following febrile status epilepticus: results of the Febstat study. Am Epilepsy Soc Abstr. doi:10.1016/j.yebeh.2016.09.013

Wills TJ, Cacucci F, Burgess N, O'Keefe J. 2010. Development of the hippocampal cognitive map in preweanling rats. Science 328: 15731576. doi:10.1126/science.1188224

Wills TJ, Barry C, Cacucci F. 2012. The abrupt development of adult-like grid cell firing in the medial entorhinal cortex. Front Neural Circuits 6: 21. doi:10.3389/fncir.2012.00021

Wilson MA, McNaughton BL. 1994. Reactivation of hippocampal ensemble memories during sleep. Science 265: 676-679. doi:10.1126/science .8036517
Winson J. 1978. Loss of hippocampal $\theta$ rhythm results in spatial memory deficit in the rat. Science 201: 160-163. doi:10.1126/science.663646

Wong RO, Chernjavsky A, Smith SJ, Shatz CJ. 1995. Early functional neural networks in the developing retina. Nature 374: 716-718. doi:10.1038/ $374716 \mathrm{a0}$

Wylie DR, Glover RG, Aitchison JD. 1999. Optic flow input to the hippocampal formation from the accessory optic system. J Neurosci 19: 5514-5527. doi:10.1523/JNEUROSCI.19-13-05514.1999

Yang YJ, Baltus AE, Mathew RS, Murphy EA, Evrony GD, Gonzalez DM, Wang EP, Marshall-Walker CA, Barry BJ, Murn J, et al. 2012. Microcephaly gene links trithorax and REST/NRSF to control neural stem cell proliferation and differentiation. Cell 151: 1097-1112. doi:10 .1016/j.cell.2012.10.043

Zola-Morgan S, Squire LR. 1993. Neuroanatomy of memory. Annu Rev Neurosci 16: 547-563. doi:10.1146/annurev.ne.16.030193.002555

Zola-Morgan S, Cohen NJ, Squire LR. 1983. Recall of remote episodic memory in amnesia. Neuropsychologia 21: 487-500. doi:10.1016/ 0028-3932(83)90005-2

Zola-Morgan S, Squire LR, Amaral DG. 1986. Human amnesia and the medial temporal region: enduring memory impairment following a bilateral lesion limited to field CA1 of the hippocampus. J Neurosci 6: 2950-2967. doi:10.1523/JNEUROSCI.06-10-02950.1986

Received December 22, 2018; accepted in revised form April 2, 2019. 


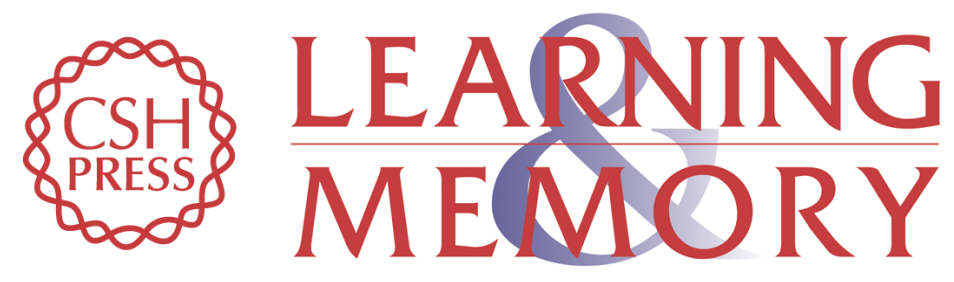

\section{Construction and disruption of spatial memory networks during development}

Tallie Z. Baram, Flavio Donato and Gregory L. Holmes

Learn. Mem. 2019, 26:

Access the most recent version at doi:10.1101/lm.049239.118

References This article cites 194 articles, 41 of which can be accessed free at: http://learnmem.cshlp.org/content/26/7/206.full.html\#ref-list-1

Creative This article is distributed exclusively by Cold Spring Harbor Laboratory Press for the Commons License first 12 months after the full-issue publication date (see

http://learnmem.cshlp.org/site/misc/terms.xhtml). After 12 months, it is available under a Creative Commons License (Attribution-NonCommercial 4.0 International), as described at http://creativecommons.org/licenses/by-nc/4.0/.

Email Alerting Receive free email alerts when new articles cite this article - sign up in the box at the Service top right corner of the article or click here. 